\title{
Hepatitis E Virus in Industrialized Countries: The Silent Threat
}

\author{
Pilar Clemente-Casares, ${ }^{1,2}$ Carlota Ramos-Romero, ${ }^{3}$ \\ Eugenio Ramirez-Gonzalez, ${ }^{1}$ and Antonio Mas $^{1,2}$ \\ ${ }^{1}$ Centro Regional de Investigaciones Biomédicas, Universidad de Castilla-La Mancha, 02008 Albacete, Spain \\ ${ }^{2}$ School of Pharmacy, Universidad de Castilla-La Mancha, 02071 Albacete, Spain \\ ${ }^{3}$ School of Medicine, Universidad de Castilla-La Mancha, 02008 Albacete, Spain
}

Correspondence should be addressed to Pilar Clemente-Casares; pilar.ccasares@uclm.es

Received 6 September 2016; Revised 7 November 2016; Accepted 15 November 2016

Academic Editor: Yanjin Zhang

Copyright (C) 2016 Pilar Clemente-Casares et al. This is an open access article distributed under the Creative Commons Attribution License, which permits unrestricted use, distribution, and reproduction in any medium, provided the original work is properly cited.

Hepatitis E virus (HEV) is the main cause of acute viral hepatitis worldwide. Its presence in developing countries has been documented for decades. Developed countries were supposed to be virus-free and initially only imported cases were detected in those areas. However, sporadic and autochthonous cases of HEV infection have been identified and studies reveal that the virus is worldwide spread. Chronic hepatitis and multiple extrahepatic manifestations have also been associated with HEV. We review the data from European countries, where human, animal, and environmental data have been collected since the 90s. In Europe, autochthonous HEV strains were first detected in the late 90s and early 2000s. Since then, serological data have shown that the virus infects quite frequently the European population and that some species, such as pigs, wild boars, and deer, are reservoirs. HEV strains can be isolated from environmental samples and reach the food chain, as shown by the detection of the virus in mussels and in contaminated pork products as sausages or meat. All these data highlight the need of studies directed to control the sources of HEV to protect immunocompromised individuals that seem the weakest link of the HEV epidemiology in industrialized regions.

\section{Introduction}

Hepatitis E virus (HEV) is the causative agent of hepatitis $\mathrm{E}$, the most frequent enterically transmitted hepatitis in the world and currently considered an important public health problem worldwide $[1,2]$. It is also the most common acute viral hepatitis, causing about $50 \%$ of acute hepatitis in developing countries [2-4]. According to WHO, one-third of the world population has been exposed to HEV [5].

The virus was discovered after an outbreak of hepatitis of unknown etiology in Kashmir valley (India), in 1978 [6], and it was molecularly characterized in 1983 [7]. HEV belongs to the family Hepeviridae that includes 2 genera: Orthohepevirus (with species that infect mammals and birds) and Piscihepevirus (infecting trout) [8]. Four genotypes have been isolated from humans and they can be classified according to their epidemiological characteristics and survival strategies. Genotypes 1 and 2 are responsible for human infections exclusively, while genotypes 3 and 4 can infect humans and other animals [5-9].

Epidemiology of HEV infection is more complex than initially thought because it includes two distinct epidemiological patterns of disease, with different characteristics [10]. Genotype 1 strains have been identified in Asia and Africa but also circulate in Cuba and Venezuela. These are frequently responsible for cases of acute hepatitis E imported to Europe by international travelers, mainly from Asia. Genotype 2 strains are found in Africa and in Mexico. Both genotypes are transmitted through fecally contaminated water, infect humans, and are associated with outbreaks [11]. Genotype 3 strains are found worldwide and affect wild and domestic mammals. This genotype causes sporadic infections in humans through zoonotic transmission or consumption of contaminated food [9]. It is responsible for most of the autochthonous cases in Europe [12]. Strains within genotype 4 are very similar to those of genotype 3, also constituting a zoonosis. Although 
some autochthonous cases caused by this genotype have been reported in Europe, the frequency is much higher in Southeastern Asia and the Far East [11].

The main routes of transmission of HEV are consumption of contaminated water and food and vertical and person-toperson transmission. Parenteral transmission is also possible $[4,13]$.

The diseases caused by the different genotypes of HEV share clinical features with other acute viral hepatitis [14]. A wide range of clinical manifestations, from asymptomatic or subclinical to acute liver failure, can be observed [15]. The current rate between infection and disease is still unknown, but it is accepted that asymptomatic infection is the most common scenario [16]. The data from an outbreak on a cruise ship caused by genotype 3 showed that $67 \%$ of the infected people were asymptomatic [17]. Patients with symptomatic disease usually suffer from jaundice, anorexia, abdominal pain, and hepatomegaly. Fever, nausea, and vomiting occur less frequently [14].

Mortality caused by HEV ( $0.2-4 \%$ in epidemics) is due to acute or subacute liver failure [4]. Among pregnant women higher incidence and severity, including fulminant hepatic failure, have been reported associated with genotype 1 strains. Mortality in this group is increased, especially in the third trimester, reaching $25-30 \%$ in areas such as northern and central India and Pakistan [2-5]. Genotype 1 has also been associated with abortion, low birth weight, and increased perinatal mortality [13], but there is scarce data about the potential of other genotypes to cause these complications [18].

Although it is mostly an acute infection, cases of chronic infection, defined as the persistence of RNA in serum or stool for 6 or more months, have been reported among immunocompromised patients $[5,19]$. These patients are at higher risk of fulminant hepatitis failure, chronification of the infection, and rapid evolution to cirrhosis [20-22].

Several extrahepatic manifestations associated with HEV infection by genotypes 1 and 3 , such as neurological disorders, have been described [23]. According to Kamar et al. [24] 5.5\% of the studied patients with acute and chronic HEV genotype 3 infections developed neurological injury. These neurological disorders include Guillain-Barré syndrome, neuralgic amyotrophy, and encephalitis/meningoencephalitis/myositis [23]. The pathophysiology of these injuries may be due to the immune response triggered by the virus or to the direct neurotrophy of the HEV. Kidney injury and hematological manifestations have also been described in HEV-infected patients [23].

\section{Seroprevalence of HEV in General Population and Blood Donors in Europe}

Although it was initially considered an enteric infection confined to developing countries, HEV has been frequently detected in industrialized countries beyond those cases imported by travelers from endemic areas since the early 2000 s. In fact, it is currently considered an emerging pathogen in developed areas [59].

In European countries, as in other developed areas, values of seroprevalence against HEV are difficult to interpret, probably due to the lack of genotype-specific assays and the wide diversity of methods employed to detect antibodies against the virus, which vary in sensitivity and specificity $[4,36,60-62]$. In fact, the analysis of a given population by using different assays usually reports very variable results $[32,36,37,39,60,62]$. Sauleda et al. [36], after testing more than 1000 serum samples in Catalonia (Spain) with two different commercial ELISA assays, obtained discordant values (19.96\% and 10.72\%). Similar results have been reported by other authors [32, 37, 39]. Probably only data obtained with the same assay should be compared [32,37]. In general, the Wantai assay gives higher seroprevalence values compared to others [62].

HEV seroprevalence varies among European countries (Table 1). Some values reported for general population are $13 \%$ in UK [25], 2.7\% in Italy [51], 1.9\% in Netherlands [43], $9.3 \%$ in Sweden [45], 16.8\% in Germany [38], 1.5\% in San Marino [63], and 7.3\% in Spain [34]. Variations are also found within countries. In France, regional differences have been observed, with values ranging from 8.0 to $86.4 \%$ [30]. In some cases, for example, Spain, seroprevalence has been reported by different authors varying from 0.8 to $7.3 \%$ [34, $35,64]$, though it is unclear whether those differences may be attributed to the assays used or to geographical differences.

As expected, values are also variable for blood donors and can be as divergent as $4.7 \%$ in Scotland and $52.2 \%$ in southwestern France. Some seroprevalence values reported for this group in different European countries are summarized in Table 1. The most interesting scenario is again southern France, where the overall seroprevalence among blood donors is $39.1 \%$ but ranges from $21.9 \%$ to $71.3 \%$ depending on the geographical area [65]. Regional differences among blood donors have also been reported in other areas in Europe, such as the Netherlands [33].

In France, Mansuy et al. [30] recently reported increased seroprevalence values when comparing blood donor samples from early 2000s and 2011-12. A similar trend was observed in the Netherlands [66]. On the contrary, some authors have reported a strong birth cohort effect in HEV seroprevalence in Denmark, with declining seroprevalence values over the last 30 years [32], probably due to lower exposure rates as a consequence of the improvement in sanitation and general living conditions. Very similar results have also been published in Germany [37].

The prevalence of anti-HEV antibodies raises with age $[25,30,33,38,67]$. Slot et al. [33] estimated a $1.05 \%$ increase of seroprevalence per year after the age of 30 among blood donors in the Netherlands. In Austria, values ranged from $8.1 \%$ in the group aged $18-19$ years to $57.5 \%$ in the group aged 50-60 years [68]. The observed increasing prevalence associated with age can be due either to a uniform exposure throughout life or to a greater exposure of the older groups [36]. IgG prevalence among children is generally less than $5 \%[25,31,35,69-71]$ and infection in this group is often asymptomatic [36].

A higher seroprevalence among male individuals has also been widely reported. Mansuy et al. [30], after analyzing more than 10000 blood donor samples, observed a significantly higher rate of exposure among men compared to women 
TABLE 1: Seroprevalence values reported among general population and blood donors in different European countries.

\begin{tabular}{|c|c|c|c|c|c|}
\hline Country & Group & Number of samples (year) & Assay & Seroprevalence & Reference \\
\hline \multirow{2}{*}{ UK } & \multirow{2}{*}{ GP } & $1591(2004)$ & \multirow{2}{*}{ FD } & $13 \%$ & \multirow{2}{*}[25]{} \\
\hline & & $1140(1991)$ & & $13.5 \%$ & \\
\hline Southwest England & $\mathrm{BD}$ & 487 & W & $15.8 \%$ & {$[26]$} \\
\hline Scotland & $\mathrm{BD}$ & 1559 & $\mathrm{~W}$ & $4.7 \%$ & {$[27]$} \\
\hline Ireland & $\mathrm{BD}$ & 1076 & W & $5.3 \%$ & {$[28]$} \\
\hline Norway & $\mathrm{BD}$ & 1200 & W & $14 \%$ & [29] \\
\hline France & $\mathrm{BD}$ & 10569 & W & $22.4 \%$ & {$[30]$} \\
\hline Southwestern France & $\mathrm{BD}$ & 512 & $\mathrm{~W}$ & $52.2 \%$ & {$[31]$} \\
\hline \multirow{2}{*}{ Denmark } & \multirow{2}{*}{$\mathrm{BD}$} & \multirow{2}{*}{504} & $\mathrm{~W}$ & $19.8 \%$ & \multirow{2}{*}[32]{} \\
\hline & & & $\mathrm{NIH}$ & $10.7 \%$ & \\
\hline Netherlands & $\mathrm{BD}$ & 5239 & $\mathrm{~W}$ & $26.7 \%$ & {$[33]$} \\
\hline Spain & GP & 1280 & BK & $7.3 \%$ & {$[34]$} \\
\hline Spain & GP & 2305 & HA & $2.17 \%$ & {$[35]$} \\
\hline \multirow{2}{*}{ Spain } & \multirow{2}{*}{$\mathrm{BD}$} & \multirow{2}{*}{1082} & W & $19.97 \%$ & \multirow[t]{2}{*}[36]{} \\
\hline & & & MK & $10.72 \%$ & \\
\hline \multirow{2}{*}{ Germany } & \multirow{2}{*}{ GP } & $1092(2011)$ & \multirow{2}{*}{ Ax } & $34.3 \%$ & \multirow{2}{*}[37]{} \\
\hline & & $1092(1996)$ & & $50.7 \%$ & \\
\hline \multirow[t]{2}{*}{ Germany } & \multirow[t]{2}{*}{ GP } & \multirow[t]{2}{*}{4422} & $r \mathrm{~L}$ & $16.8 \%$ & \multirow[t]{2}{*}[38]{} \\
\hline & & & MP & $4.9 \%$ & \\
\hline \multirow[t]{2}{*}{ Southwest Switzerland } & \multirow[t]{2}{*}{$\mathrm{BD}$} & \multirow[t]{2}{*}{550} & DP & $4.2 \%$ & \multirow[t]{2}{*}[39]{} \\
\hline & & & FD & $21.8 \%$ & \\
\hline Greece & $\mathrm{BD}$ & 265 & Adaltis & $9.43 \%$ & {$[40]$} \\
\hline
\end{tabular}

$\mathrm{GP}=$ general population.

$\mathrm{BD}=$ blood donors.

Assays: FD = Fortress Diagnostics (identical to Wantai), W = Wantai, NIH = NIH in-house assay, BK = Biokit, HA = HEV Ab, MK = Mikrogen ELISA test, Ax $=$ Axcom, $\mathrm{MP}=\mathrm{MP}$ Diagnostics, $\mathrm{DP} / \mathrm{A}=\mathrm{Dia}$. Pro/Adaltis, and $r \mathrm{~L}=$ recomLine Mikrogen (Western Blot).

(25\% versus $19.5 \%)$. Similar trends have been reported by several other groups $[33,34,36,70,72]$. On the contrary, other studies did not find significant differences by gender $[40,73,74]$.

\section{Acute and Chronic Hepatitis $\mathbf{E}$}

In Europe, $5-15 \%$ of the acute hepatitis of unknown origin are caused by HEV $[67,75-79]$. In the 90s, the diagnosed patient would have probably traveled to an endemic area and come back to Europe with an imported HEV strain. In the late 90 s and early 2000s, the first autochthonous cases of HEV infections by genotype 3 were reported [80-83]. Since then, similar cases locally acquired have been reported regularly throughout Europe [26, 67, 84-93]. Nowadays, the profile of the patient suffering from an acute $\mathrm{E}$ hepatitis is a man older than 40 with no travel history to endemic areas.

As expected, most of the acute hepatitis E cases reported in Europe are asymptomatic and self-limited infections. It has been reported that some symptomatic HEV infections may be misdiagnosed as drug-induced liver injury [76]. Although autochthonous acute hepatitis E cases in Europe are preferentially caused by genotype 3 strains, some genotype 4 autochthonous cases have recently been detected in France, Denmark, Italy, and Germany [90, 94-98]. Likewise, imported infections are also diagnosed, usually from immigrants or travelers coming back from Asia, Africa, and South America [67, 90, 91, 93, 99]. These infections are typically due to genotype 1 strains, although some cases caused by genotype 4 have also been identified $[98,100,101]$. In general, individuals with imported $\mathrm{HEV}$ infections are younger than those with locally acquired ones $[84,90]$.

Some cases of fulminant hepatitis have also been described [102-110]. Immunocompromised patients in Europe include HIV-infected patients [111-115], solid-organ transplant (SOT) recipients $[15,19,116-126]$, and individuals under immunosuppressive therapy or with hematological diseases [126-131]. Chronic hepatitis E is caused by genotype 3 strains [9], although one recently described case has been associated with genotype 4 [132]. According to some authors, the reduction of immunosuppressive therapy (if possible) or treatments with ribavirin or pegylated-interferon plus ribavirin may induce the clearance of the virus $[15,114,125,131]$. In Spain, one chronic HEV infection was identified in an immunocompetent man as reported by Gonzalez Tallon et al. [133].

Cases of neurological disorders associated with HEV infections have also been detected in Europe. van den Berg et al. [134] concluded that 5\% of patients with GuillainBarré syndrome in the Netherlands had an associated HEV infection. Acute HEV infection was also detected in $10 \%$ of 
patients with neuralgic amyotrophy in UK and the Netherlands [135]. Although Guillain-Barré syndrome and neuralgic amyotrophy are the most frequently reported neurological disorders, encephalitis, meningitis, peripheral neuropathy, or polyradiculoneuropathy has been also described in $\mathrm{HEV}$ infected patients in Europe [24, 136-139].

\section{HEV in Animals}

HEV genotypes 3 and 4 have been identified in multiple species. In 1997, Meng et al. [140] reported for the first time the detection of the virus in pigs in the United States. Since then, HEV has been isolated from different species such as deer, wild boar, monkey, mongoose, rabbit, ferret, trout, bat, rat, chicken, kestrel, falcon, camel, and trout [141]. However, only pigs, wild boars, and deer are considered true reservoirs of the virus for humans [142]. Pigs, usually with subclinical infection, are considered the most important among them [9].

In Europe, high HEV seroprevalence has been detected in swine from Spain [143, 144], Italy [145-147], Norway [29], Denmark [148], UK [149, 150], Estonia [151], Germany [152, $153]$, or Switzerland $[154,155]$. According to the seroprevalence data, $76 \%$ to $98 \%$ of Spanish swine farms have evidence of HEV presence [143, 144, 156, 157]. Some farms are virusfree, while in others up to $100 \%$ of the animals have detectable IgG levels [143, 144]. In Germany, Baechlein [158] showed that in $78.2 \%$ of the investigated farms at least one seropositive animal was identified, reaching $100 \%$ in some areas.

Seminati et al. [144] studied the dynamics of infection in a seropositive farm. They analyzed the presence of antibodies and viral RNA in different groups of age and concluded that circulation of HEV usually occurs at the end of the nursery or the beginning of the fattening period. It is widely accepted that breeding sows can play a role as HEV reservoirs and can transmit the virus to sucking piglets $[144,148,156$, 159, 160]. Pigs of less than 2 months are protected against HEV infection due to the presence of maternal antibodies $[140,161,162]$. HEV infection in pigs is subclinical, with only microscopic liver lesions [140, 163].

Although infection in pigs seems to occur at early stages in animal life, virus can be detected at all ages [156, 160, $162,164]$. On the other hand, RNA has been found in feces, liver, bile, and cecal content of animals at slaughter age, representing a risk of entrance of $\mathrm{HEV}$ into the food chain $[149,150,157,160]$. Casas et al. [160] identified the virus in liver or bile of 3 animals at slaughter age 3 months after the first reports of their infection. If those cases were due to persistent infections in those organs or reinfections remains unknown, although the sequences in one of the animals were different enough to assume reinfection.

Wild boar and deer populations are also considered HEV reservoirs in Europe. In Spain the seroprevalence values among wild boars range from $26.3 \%$ to $57.4 \%$ [165-167]. Similar results were observed in Italy, (29.2\% [147] and 40.7\% [168]), Germany (41\% [169]), Belgium (34\% [170]), or Poland (44.4\% [171]). Lower values have been observed among deer populations, for example, red deer (10,4\% [172], 12,85\% [165],
$2-3.3 \%$ [173], 8\% [174], and 1\% [170]), roe deer $(5.4-6.8 \%$ [173], 3\% [170]), and moose [175].

HEV strains isolated from pigs, wild boars, and deer in Europe belong to genotype $3[146,149,156,165,166,168$, 172, 176-178], although genotype 4 strains have also been detected in pigs in Belgium and Italy $[95,179,180]$. Swine $\mathrm{HEV}$ isolates are usually highly related to $\mathrm{HEV}$ sequences isolated from humans in the same area, that is, exhibiting even more similarities with human sequences than with swine sequences isolated from different regions [156, 157, 181]. Likewise similarities between HEV sequences isolated from wild boar, deer, and domestic pigs can be as high as $99 \%$, which may be considered as further evidence of transmission between them $[166,167,172]$.

Other animal species infected by HEV in Europe are rabbit, goat, rat, ferret, and mink, although phylogenetic studies mostly show high divergence with human HEV strains. Di Bartolo et al. [182] studied the presence of antibodies against $\mathrm{HEV}$ in farmed and pet rabbits in Italy, reporting seroprevalence of $3.4 \%$ and $6.56 \%$, respectively, but no HEV RNA was found. In France, Izopet et al. [183] detected the virus in bile samples from farmed rabbits (7\%) and in liver samples from wild rabbits (23\%), with all the strains detected clustered and forming a clade clearly separated from genotypes 1 to 4 . Furthermore, some of those rabbit strains were very similar to HEV strain from a man also from France [183]. HEV infecting rabbits has also been detected in Germany [184] and the Netherlands [185] and from a pet house rabbit in Italy [186].

Very recently, Di Martino et al. [187] described genotype 3 strains infecting goats in Italy. Antibodies against HEV had already been detected in goats $(0.6 \%)$ in Spain, as well as in sheep (1.92\%) and cats (11.11\%) [188]. McElroy et al. [189] showed that dogs in the UK are also susceptible to HEV infection (seroprevalence of $0.8 \%$ ).

Rat HEV strains have been detected in Germany, where a survey in different areas showed a broad geographical distribution of the virus in Norway rats with an overall seroprevalence of $24.5 \%$ [190] and in Denmark [191]. Stalin Raj et al. [192] detected HEV RNA in $9.3 \%$ of fecal samples collected from household pet ferrets without overt clinical signs. The sequences clustered with rat HEV.

Finally, the presence of HEV among birds has also been reported in Europe. Marek et al. [193] demonstrated a wide spreading of the avian HEV in chicken flocks in Europe. Peralta et al. [194] reported that $89.7 \%$ of the Spanish chicken flocks analyzed in their study had at least 1 seropositive animal. The isolated strains were similar to other avian HEV sequences previously isolated in USA and Canada, although forming a different genetic cluster. Reuter et al. [195] found $\mathrm{HEV}$ in common kestrels and red-footed falcons in Hungary. The sequence detected in a kestrel was more related to ferret and rats HEV isolates than to any other avian.

\section{HEV in Environment and Food}

Many viruses reach the environment and can infect people via water and food. HEV is excreted in feces [196] and has also been detected in urine $[197,198]$. These viral particles can reach the environment and contaminate water sources 
and irrigated food. In fact, drinking contaminated water is the main mode of transmission of the virus in developing countries [142].

HEV can be detected in sewage. Multiple studies performed in Spain detected the presence of HEV in urban and slaughterhouse sewage [83, 181, 199-201]. Some of those studies isolated the virus from more than $30 \%$ of the raw urban sewage samples tested [181, 201]. The virus has also been detected in sewage from Italy [202, 203], France [204], or Norway [205]. Although sewage is treated before being released to the environment, conventional wastewater treatment does not completely remove all viruses [206]. Rusiñol et al. [206] studied the elimination of HEV during wastewater treatment by testing influent raw sewage and secondary and tertiary treated effluents from a wastewater treatment plant. Although the virus is present in raw sewage and secondary effluent, it was not detected in the tertiary effluent samples. Myrmel et al. [205] also detected HEV in secondary treated water.

HEV can be concentrated in some waste products generated during sewage and drinking water treatments (i.e., sludge and biosolid) [200, 207, 208]. Land application of this waste can contaminate water from aquifers and vegetables irrigated. Kokkinos et al. [209] reported the presence of $\mathrm{HEV}$ in $5 \%$ of the irrigation water samples tested from the leafy green vegetables production chain. In another study, the authors also detected 4 samples (3.2\%) of fresh lettuce contaminated with the virus [210]. HEV has also been detected from frozen raspberries (1/38) [211]. Renou et al. [212] identified consumption of water from springs or private wells and vegetables from gardens irrigated with those water sources as risk factors for acquiring hepatitis $\mathrm{E}$ infection in France. In Slovenia, Steyer et al. [213] found HEV in surface water samples, one of them collected near a pig farm. In fact, the identity with other Slovenian swine HEV isolates in the area was $100 \%$. The virus was also detected in a river sample in Italy [214] and the Netherlands [215].

Run-offs from animal facilities have been implicated in human $\mathrm{HEV}$ infections as the virus has been detected in manure and wastewater with animal fecal contamination $[215,216]$. It is also present in slurry samples from pig manure composting plants in Spain and other European regions [164, 217, 218]. In the Spanish study [217], the authors concluded that composting process was effective in eliminating $\mathrm{HEV}$ from the slurries.

Routes of food contamination are diverse and include those already mentioned (i.e., application of organic wastes to agricultural land as fertilizer and contamination of water used for irrigation with fecal material) and also direct contamination by livestock, wild animals, and birds as well as postharvest issues such as worker hygiene [219]. The consumption of meat from HEV-infected animals is a source of HEV transmission to human and a public health concern [220]. In fact, some cases of direct transmission have already been documented in Europe [221, 222] and others have been indirectly associated with contaminated food [204, 223, 224]. Although the virus replicates in liver, it has also been detected in other tissues such as stomach, kidney, or multiple muscle masses $[160,225]$. HEV have been detected in the food chain of pork products in the Netherlands [226], France [223, 227], Germany [228], Italy [176], Czech Republic [176], and Spain $[176,229]$. This may not be uncommon if animals at slaughter age can be actively infected by the virus $[149,160]$. Di Bartolo et al. [176] detected HEV, not only in packaged sausages and liver samples from processing sites and supermarkets in Spain, Italy, and Czech Republic but also from environmental samples collected in production farms and processing plants and at the points of sale in items such as knives, floor, belt surfaces, workers' hands, and toilets. HEV-positive samples were found more frequently at slaughterhouses than at processing and points of sale. In Canada, Nantel-Fortier et al. [230] recently found that movements of trucks and utility vehicles might play an important role in HEV dissemination on a slaughterhouse site and throughout the entire network.

The analysis of meat samples confiscated to passengers in the International Airport of Bilbao (Spain) on flights from non-European countries in 2012 and 2013 revealed that $53.3 \%$ of these samples were positive for HEV, including pork, poultry, beef, sheep, antelope, or kangaroo samples [229]. Contamination of food products during the manipulation via human handlers in the place of origin may explain the high percentage of HEV-positive samples among nonpork meat products found by the authors, some isolates being genotypes 1 and 2. The estimated viral load was very low and no data about infectivity was provided.

Coastal waters may also be contaminated by HEV leading to accumulation of the virus in the digestive tissues of shellfish due to their filter-feeding nature $[220,231]$ and processing interventions such as depuration do not completely remove viral particles [232]. Some studies have detected HEV in mussels or oysters. In Spain, Mesquita et al. [233] found that $15 \%$ of mussels batches tested from Galicia (Spain) were contaminated by the virus. In a similar study, Diez-Valcarce et al. [231] analyzed commercial mussels obtained at local retail stores in Spain and Finland, obtaining 6\% of positive samples in the Spanish specimens. Analogously, HEV accumulation in shellfish has also been described in Scotland [234]. Thus contaminated bivalve mollusks suppose a health risk for people who eat them raw or slightly cooked [234, 235]. HEV outbreak on a cruise ship was associated with consumption of shellfish, although the source was not identified [17].

\section{Routes of Transmission and Risk Groups}

Travelers returning from HEV endemic areas were the first risk group considered in industrialized countries. In fact, although autochthonous strains are gaining increased importance, the imported cases are still frequently diagnosed, usually associated with genotype 1 strains $[67,88,104,108,109$, 236].

Consumption of contaminated water is the major route of transmission of the infection in developing countries, but this is not the case in industrialized countries, where sanitation conditions are supposed to be better. However, also in these areas, consumption of untreated water is also considered a risk for $\mathrm{HEV}$ infection [237]. In this study conducted in Spain, consumption of untreated water from water fountains 
TABLE 2: Risk groups reported in Europe with increased HEV seroprevalence when compared to a control group. Only studies that analyze a control group are included in the table.

\begin{tabular}{|c|c|c|c|c|c|}
\hline \multirow{2}{*}{ Risk factor } & \multirow{2}{*}{ Risk group } & \multirow{2}{*}{ Country } & \multicolumn{2}{|c|}{ Seroprevalence } & \multirow{2}{*}{ Reference } \\
\hline & & & Risk group & Control group & \\
\hline \multirow{11}{*}{ Contact with animals } & Pig farm workers & \multirow{2}{*}{ France } & $44 \%$ & \multirow{2}{*}{$26 \%$} & \multirow{2}{*}[41]{} \\
\hline & Forestry workers & & $36 \%$ & & \\
\hline & Forestry workers & France & $31.2 \%$ & $19.2 \%$ & {$[42]$} \\
\hline & Swine veterinarians & \multirow{2}{*}{ Netherlands } & $11 \%$ & \multirow{2}{*}{$2 \%$} & \multirow{2}{*}[43]{} \\
\hline & Nonswine veterinarians & & $6 \%$ & & \\
\hline & Farmers & Denmark & $50.3 \%$ & $32.9 \%$ & {$[44]$} \\
\hline & Swine farmers & Sweden & $13 \%$ & $9 \%$ & {$[45]$} \\
\hline & Swine farmers & Moldova & $51.1 \%$ & $24.7 \%$ & {$[46]$} \\
\hline & Animal breeders & Italy & $25.6 \%$ & $0 \%$ & {$[47]$} \\
\hline & Slaughterers & Germany & $41.7 \%$ & $15.5 \%$ & {$[48]$} \\
\hline & Forestry workers & Germany & $18 \%$ & $11 \%$ & [49] \\
\hline Contact with sewage & Agricultural workers & Turkey & $34.8 \%$ & $4.4 \%$ & {$[50]$} \\
\hline \multirow{10}{*}{ Immunosuppression } & HIV patients & Italy & $6.7 \%$ & $2.7 \%$ & [51] \\
\hline & HIV patients & \multirow{2}{*}{ Spain } & $9.2 \%$ & \multirow{2}{*}{$3.5 \%$} & \multirow{2}{*}{ [52] } \\
\hline & HIV patients with cirrhosis & & $22.7 \%$ & & \\
\hline & HIV patients & \multirow{2}{*}{ Spain } & $23.5 \%$ & $12 \%$ & \multirow[t]{2}{*}[53]{} \\
\hline & $\mathrm{HIV}+\mathrm{HCV}$ patients & & $40 \%$ & & \\
\hline & Autoimmune hepatitis patients & Germany & $7.7 \%$ & $2.0 \%$ & {$[54]$} \\
\hline & Hemodialysis patients & Italy & $6 \%^{*}$ & $2.7 \%$ & {$[55]$} \\
\hline & Hemodialysis patients & UK & $36.8 \%$ & $18.8 \%$ & {$[56]$} \\
\hline & Post-liver transplant cirrhosis & Spain & $32.1 \%$ & $3.5 \%$ & {$[52]$} \\
\hline & Heart transplant & Germany & $11.3 \%$ & $2 \%$ & [57] \\
\hline \multirow{2}{*}{ Preexisting liver diseases } & HCV patients & Spain & $23.5 \%$ & $12 \%$ & [53] \\
\hline & Chronic liver disease patients & Albania & $36.6 \%$ & $12.1 \%$ & {$[58]$} \\
\hline
\end{tabular}

* No significant difference found.

near swine farms was associated with higher seroprevalence. Similarly, Mansuy et al. [30] found that drinking bottled water was associated with a lower risk of HEV IgG in France.

Exposition to HEV susceptible animals, mostly swine and wild game species, that is, wild boar and deer, is usually considered a risk factor for acquiring an $\mathrm{HEV}$ infection (Table 2). In Spain, Galiana et al. [237] compared the presence of IgG against HEV in people exposed to swine (farmers, handlers, and veterinarians) versus nonexposed individuals (controls) and found significantly higher values among the former (18.8\% versus $4 \%$ ), which confirmed the higher risk of acquiring HEV among people in contact with pigs. Similar results were obtained in the Netherlands and France [41, 43]. In Norway, increased seroprevalence has recently been reported in swine farm workers, but not among veterinarians [29]. In Spain, a case of acute hepatitis E in a slaughterhouse worker, probably infected after manipulating HEV-infected animals, was reported [238]. However, Meader et al. [239] did not identify farm contact with pigs as a risk factor for HEV infection.

Other professional and recreational activities have been associated with an increased risk of acquiring $\mathrm{HEV}$ such as hunters and forestry workers, suggesting that animal stools may provide an additional source of $\mathrm{HEV}$ infection among people with close contact with the forest environment [42, $49,240]$. In Turkey, agricultural workers who used untreated wastewater for irrigation showed a seroprevalence value of $34.8 \%$ compared to the $4.4 \%$ found in the control group [50]. On the contrary, in Germany, some studies concluded that sewage is not a source of infection for sewage workers $[241,242]$.

Consumption of raw or undercooked meat has also been suggested as a risk factor for HEV infection because of the following: (a) the virus is frequently isolated from animals at slaughter age and meat products at point-of-sale [149, $150,176,223,227]$, (b) it is unknown how long the virus can survive in an infectious state in food products [243], (c) some studies indicate that HEV can survive and keep infectivity at temperatures used in some cooking regimens $[244,245]$, and (d) the consumption of raw or undercooked meat has been frequently identified as risk factor for $\mathrm{HEV}$ infection [30, 41, 65, 246]. In Spain, Riveiro-Barciela et al. [222] described the zoonotic origin of an acute hepatitis $\mathrm{E}$ in an immunocompromised patient after pork meat ingestion. Identical HEV sequences were isolated from the patient and a leftover frozen piece of meat. This transmission route provides a plausible explanation for the high seroprevalence observed in the general population without other risk factors 
and it is supported by the high similarity observed between human and animal HEV isolates from the same area $[9,140$, 181, 247]. The transmission of the HEV by consumption of raw meat has also been demonstrated for meat products derived from wild boar [248] and deer [249] in Japan. Recreational hunting of wild boars and further consumption of their meats provide an ideal condition for the transmission of pathogens such as HEV [250, 251]. Consumption of shellfish is another risk factor described frequently in Europe [65, 231, 233].

In Spain, IgG seroprevalence among pregnant women varies from 0.6 to $5.4 \%$, similar to the prevalence in general population [252-254]. IgM seroprevalence reported was $0.67 \%$ [254], suggesting that although subclinical infections exist, prevalence is very low. In France, authors conclude that HEV infection during pregnancy is rare even in areas with high seroprevalence [255]. In fact, only few cases of HEV infection during pregnancy have been reported in Europe $[256,257]$ and no complications were described. The predominance of genotype 3 , which seems to be less virulent than other genotypes, is one of the possible explanations for the different outcome of the infection related to endemic areas [254]. One case of fulminant hepatitis E in a woman with oral contraceptive treatment was described by Mateos Lindemann et al. [103].

Immunocompromised subpopulations are also considered groups of risk for HEV. In Europe, reported seroprevalence among HIV ranges from $1 \%$ to $26 \%[52,258-265]$ with some countries, for example, Spain, with values ranging from 9 to $26 \%$ depending on the study $[52,53,259,260,266-$ 268]. According to some authors, HIV infection seems to be a risk factor, not for acquiring an HEV infection, but for developing a chronic infection. Studies in Germany [269], Spain [53], and UK [270] reported no significant differences in HEV seroprevalence among HIV patients when compared to the general population. Pischke et al. [269] also concluded that the risk of developing chronic infection was very low if those patients were properly treated. Something similar was reported by other authors [270, 271]. In some studies, low $\mathrm{CD}^{+} \mathrm{T}$ cell counts have been associated with higher risk of HEV infection [260, 265]. Jardi et al. [259] concluded that the only factor associated with HEV IgG detection among HIV patients was the presence of liver cirrhosis $(23 \%$ in patients with cirrhosis versus $6 \%$ in patients without cirrhosis), suggesting that individuals with cirrhosis are at a high risk of acquiring HEV infection [259]. This has also been reported by other authors $[19,260]$.

Solid-organ transplant (SOT) recipients are usually immunocompromised and, in addition to the fecal-oral route of transmission of the HEV, they can also get infected by administration of blood products and via the transplanted organ [272]. Some studies in Europe have reported cases of HEV infection after transplant, most of them asymptomatic. In France, Kamar et al. [19] reported that 14 out of 217 (6.5\%) SOT patients had detectable HEV RNA and 8 developed chronic HEV infection. In the Netherlands, Haagsma et al. [273] concluded that SOT recipients had increased risk of developing a chronic HEV infection but that the prevalence of posttransplant infection was low (1-2\%). According to Riveiro-Barciela et al. [52], similar to HIV patients, SOT recipients with liver cirrhosis are prone to HEV infection, especially if the cirrhosis appeared after the transplantation. In some cases when the disease evolves to cirrhosis, a retransplantation of the liver is needed [274]. On the contrary, Buffaz et al. [275] concluded that liver transplant patients may not be particularly prone to developing severe HEV infections.

Patients with preexisting liver disease, mainly by other hepatotropic viruses, can also display higher prevalence than the general population [53]. In Albania, seroprevalence among patients with chronic liver disease (HBV, HCV, and HDV infections) was $36.6 \%$ versus $12.1 \%$ among controls [58]. However, Pischke et al. [54] concluded that HCV/HBC patients did not present higher risk of HEV infections compared to controls. On the other hand, increased severity of infection in this group has been suggested [87]. BlascoPerrin et al. [276], however, concluded that mortality among HEV patients with and without decompensated chronic liver disease was similar.

Although some authors point out that hemodialysis patients may be a group of risk for HEV [277], the results in Europe are unclear. While some authors reported higher seroprevalence among this group [56, 278], others did not find significant differences when compared to the controls $[55,279,280]$.

Patients treated with immunosuppressants are also supposed to be at risk of HEV infection. Pischke et al. [54] reported that patients with autoimmune hepatitis were more likely to test HEV-positive than controls. However, Senosiain et al. [281] found a lower prevalence among patients with inflammatory bowel disease than for the general population. Similarly, Bauer et al. [282] studied the HEV infection in patients with inflammatory arthritides under immunosuppressive therapy, but no chronic infection was observed.

HEV transmission through blood products has been described in France and the UK [283-285]. In fact the screening of blood donors samples in Europe has reported prevalences of viral RNA of $0.03 \%$ in Spain [36], $0.045 \%$ in France [286], 0.012\% in Austria [287], 0.04\% in UK [288], $0.076 \%$ in the Netherlands [289], or $0.081 \%$ in Germany [290]. Although very few cases of transmission by this route have been documented, the active viremia found in donors suggests the possibility of parenteral transmission. Indeed, some authors suggest the need for a systematic screening of blood donations by detecting HEV RNA [291].

In conclusion, according to the published data, HEV is widespread among industrialized countries. Some animal species may act as reservoirs for the infection, preferentially swine, but also wild boar or deer. The main routes of transmission are contact with infected animals and the consumption of contaminated food, usually pork products. Therefore, higher control measures to detect contaminated food and to avoid professional exposure to HEV should be implemented. Blood components can also be a source of virus and should be screened. Although frequently self-limited, infections sometimes evolve to chronic infection in immunosuppressed individuals and this may lead to cirrhosis. There is a need to improve the HEV diagnostic in previously considered virusfree areas, especially among immunocompromised patients 
with elevated liver enzymes levels and those with preexisting hepatic alterations, as they may suffer faster deterioration of the liver function. Information and advice to prevent infection should also be given to these groups.

\section{Competing Interests}

The authors declare that there is no conflict of interests regarding the publication of this paper.

\section{References}

[1] J. Petrik, M. Lozano, C. R. Seed et al., “Hepatitis E.,” Vox Sanguinis, vol. 110, no. 1, pp. 93-130, 2016.

[2] M. T. Pérez-Gracia, M. García, B. Suay, and M. L. MateosLindemann, "Current knowledge on hepatitis E," Journal of Clinical and Translational Hepatology, vol. 3, no. 2, pp. 117-126, 2015.

[3] M. S. Khuroo, "Discovery of hepatitis E: the epidemic nonA, non-B hepatitis 30 years down the memory lane," Virus Research, vol. 161, no. 1, pp. 3-14, 2011.

[4] N. Kamar, R. Bendall, F. Legrand-Abravanel et al., "Hepatitis E," The Lancet, vol. 379, no. 9835, pp. 2477-2488, 2012.

[5] M. S. Khuroo and M. S. Khuroo, "Hepatitis E: an emerging global disease-from discovery towards control and cure," Journal of Viral Hepatitis, vol. 23, no. 2, pp. 68-79, 2016.

[6] M. S. Khuroo, "Study of an epidemic of non-A, non-B hepatitis. Possibility of another human hepatitis virus distinct from posttransfusion non-A, non-B type," The American Journal of Medicine, vol. 68, no. 6, pp. 818-824, 1980.

[7] M. S. Balayan, A. G. Andjaparidze, S. S. Savinskaya et al., "Evidence for a virus in non-A, non-B hepatitis transmitted via the fecal-oral route," Intervirology, vol. 20, no. 1, pp. 23-31, 1983.

[8] D. B. Smith, P. Simmonds, S. Jameel et al., "Consensus proposals for classification of the family Hepeviridae," Journal of General Virology, vol. 95, part 10, pp. 2223-2232, 2014.

[9] S. Sridhar, S. K. P. Lau, and P. C. Y. Woo, "Hepatitis E: a disease of reemerging importance," Journal of the Formosan Medical Association, vol. 114, no. 8, pp. 681-690, 2015.

[10] R. Aggarwal and S. Naik, "Epidemiology of hepatitis E: current status," Journal of Gastroenterology and Hepatology, vol. 24, no. 9, pp. 1484-1493, 2009.

[11] J. M. Echevarria, M. Fogeda, and A. Avellon, "Epidemiology of hepatitis E virus infection in Spain," Enfermedades Infecciosas y Microbiología Clínica, vol. 33, no. 4, pp. 281-286, 2015.

[12] D. Lapa, M. R. Capobianchi, and A. R. Garbuglia, "Epidemiology of hepatitis E virus in European countries," International Journal of Molecular Sciences, vol. 16, no. 10, pp. 25711-25743, 2015.

[13] S. Mirazo, N. Ramos, V. Mainardi, S. Gerona, and J. Arbiza, "Transmission, diagnosis, and management of hepatitis E: an update," Hepatic Medicine, vol. 6, pp. 45-59, 2014.

[14] J. M. Echevarria, "Autochthonous hepatitis e virus infection in Europe: a matter of concern for public health?" Journal of Clinical and Translational Hepatology, vol. 2, no. 1, pp. 7-14, 2014.

[15] S. Lens, L. Mensa, M. Gambato et al., "HEV infection in two referral centers in Spain; epidemiology and clinical outcomes," Journal of Clinical Virology, vol. 63, pp. 76-80, 2015.
[16] J. M. Echevarría, "Light and darkness: prevalence of hepatitis E virus infection among the general population," Scientifica, vol. 2014, Article ID 481016, 14 pages, 2014.

[17] B. Said, S. Ijaz, G. Kafatos et al., "Hepatitis E outbreak on cruise ship," Emerging Infectious Diseases, vol. 15, no. 11, pp. 1738-1744, 2009.

[18] L. J. Krain, J. E. Atwell, K. E. Nelson, and A. B. Labrique, "Fetal and neonatal health consequences of vertically transmitted hepatitis E virus infection," The American Journal of Tropical Medicine and Hygiene, vol. 90, no. 2, pp. 365-370, 2014.

[19] N. Kamar, J. Selves, J.-M. Mansuy et al., "Hepatitis E virus and chronic hepatitis in organ-transplant recipients," New England Journal of Medicine, vol. 358, no. 8, pp. 811-817, 2008.

[20] A. I. G. Tallón, V. M. Vicente, and M. L. M. Lindemann, "Chronic hepatitis E," Medicina Clinica, vol. 138, no. 2, pp. 69-72, 2012.

[21] S. Fujiwara, Y. Yokokawa, K. Morino, K. Hayasaka, M. Kawabata, and T. Shimizu, "Chronic hepatitis e: a review of the literature," Journal of Viral Hepatitis, vol. 21, no. 2, pp. 78-89, 2014.

[22] J. Versluis, S. D. Pas, H. J. Agteresch et al., "Hepatitis E virus: an underestimated opportunistic pathogen in recipients of allogeneic hematopoietic stem cell transplantation," Blood, vol. 122, no. 6, pp. 1079-1086, 2013.

[23] N. Kamar, O. Marion, F. Abravanel, J. Izopet, and H. R. Dalton, "Extrahepatic manifestations of hepatitis E virus," Liver International, vol. 36, no. 4, pp. 467-472, 2016.

[24] N. Kamar, R. P. Bendall, J. M. Peron et al., "Hepatitis E virus and neurologic disorders," Emerging Infectious Diseases, vol. 17, no. 2, pp. 173-179, 2011.

[25] S. Ijaz, A. J. Vyse, D. Morgan, R. G. Pebody, R. S. Tedder, and D. Brown, "Indigenous hepatitis E virus infection in England: more common than it seems," Journal of Clinical Virology, vol. 44, no. 4, pp. 272-276, 2009.

[26] H. R. Dalton, W. Stableforth, S. Hazeldine et al., "Autochthonous hepatitis E in southwest England: a comparison with hepatitis A," European Journal of Clinical Microbiology \& Infectious Diseases, vol. 27, no. 7, pp. 579-585, 2008.

[27] A. Cleland, L. Smith, C. Crossan et al., "Hepatitis E virus in Scottish blood donors," Vox Sanguinis, vol. 105, no. 4, pp. 283289, 2013.

[28] J. O’Riordan, F. Boland, P. Williams et al., "Hepatitis E virus infection in the Irish blood donor population," Transfusion, vol. 56, no. 11, pp. 2868-2876, 2016.

[29] H. Lange, J. Øverbø, K. Borgen et al., "Hepatitis E in Norway: seroprevalence in humans and swine," Epidemiology and Infection, vol. 145, no. 1, pp. 181-186, 2016.

[30] J. M. Mansuy, P. Gallian, C. Dimeglio et al., "A nationwide survey of hepatitis E viral infection in French blood donors," Hepatology, vol. 63, no. 4, pp. 1145-1154, 2016.

[31] J.-M. Mansuy, R. Bendall, F. Legrand-Abravanel et al., "Hepatitis E virus antibodies in blood donors, France," Emerging Infectious Diseases, vol. 17, no. 12, pp. 2309-2312, 2011.

[32] D. K. Holm, B. K. Moessner, R. E. Engle et al., "Declining prevalence of hepatitis E antibodies among Danish blood donors," Transfusion, vol. 55, no. 7, pp. 1662-1667, 2015.

[33] E. Slot, B. M. Hogema, A. Riezebos-Brilman, T. M. Kok, M. Molier, and H. L. Zaaijer, "Silent hepatitis E virus infection in Dutch blood donors, 2011 to 2012," Eurosurveillance, vol. 18, no. 31, 2013.

[34] M. Buti, À. Domínguez, P. Plans et al., "Community-based seroepidemiological survey of hepatitis E virus infection in Catalonia, Spain," Clinical and Vaccine Immunology, vol. 13, no. 12, pp. 1328-1332, 2006. 
[35] M. Fogeda, A. Avellón, and J. M. Echevarría, "Prevalence of specific antibody to hepatitis E virus in the general population of the community of Madrid, Spain," Journal of Medical Virology, vol. 84, no. 1, pp. 71-74, 2012.

[36] S. Sauleda, E. Ong, M. Bes et al., "Seroprevalence of hepatitis E virus (HEV) and detection of HEV RNA with a transcriptionmediated amplification assay in blood donors from Catalonia (Spain)," Transfusion, vol. 55, no. 5, pp. 972-979, 2015.

[37] J. J. Wenzel, M. Sichler, M. Schemmerer, G. Behrens, M. F. Leitzmann, and W. Jilg, "Decline in hepatitis E virus antibody prevalence in southeastern Germany, 1996-2011," Hepatology, vol. 60, no. 4, pp. 1180-1186, 2014.

[38] M. S. Faber, J. J. Wenzel, W. Jilg, M. Thamm, M. Höhle, and K. Stark, "Hepatitis e virus seroprevalence among adults, Germany," Emerging Infectious Diseases, vol. 18, no. 10, pp. 16541657, 2012.

[39] A. Schnegg, P. Bürgisser, C. André et al., "An analysis of the benefit of using HEV genotype 3 antigens in detecting AntiHEV IgG in a European population," PLOS ONE, vol. 8, no. 5, Article ID e62980, 2013.

[40] T. Pittaras, S. Valsami, M. Mavrouli, V. Kapsimali, A. Tsakris, and M. Politou, "Seroprevalence of hepatitis E virus in blood donors in Greece," Vox Sanguinis, vol. 106, no. 4, p. 387, 2014.

[41] H. Chaussade, E. Rigaud, A. Allix et al., "Hepatitis E virus seroprevalence and risk factors for individuals in working contact with animals," Journal of Clinical Virology, vol. 58, no. 3, pp. 504508, 2013.

[42] A. Carpentier, H. Chaussade, E. Rigaud et al., "High hepatitis E virus seroprevalence in forestry workers and in wild boars in France," Journal of Clinical Microbiology, vol. 50, no. 9, pp. 28882893, 2012.

[43] M. Bouwknegt, B. Engel, M. M. P. T. Herremans et al., "Bayesian estimation of hepatitis $\mathrm{E}$ virus seroprevalence for populations with different exposure levels to swine in The Netherlands," Epidemiology and Infection, vol. 136, no. 4, pp. 567-576, 2008.

[44] P. B. Christensen, R. E. Engle, C. Hjort et al., "Time trend of the prevalence of hepatitis $\mathrm{E}$ antibodies among farmers and blood donors: a potential zoonosis in Denmark," Clinical Infectious Diseases, vol. 47, no. 8, pp. 1026-1031, 2008.

[45] B. Olsen, D. Axelsson-Olsson, A. Thelin, and O. Weiland, "Unexpected high prevalence of IgG-antibodies to hepatitis E virus in Swedish pig farmers and controls," Scandinavian Journal of Infectious Diseases, vol. 38, no. 1, pp. 55-58, 2006.

[46] J. Drobeniuc, M. O. Favorov, C. N. Shapiro et al., "Hepatitis E virus antibody prevalence among persons who work with swine," Journal of Infectious Diseases, vol. 184, no. 12, pp. 15941597, 2001.

[47] R. Tabibi, R. Baccalini, A. Barassi et al., "Occupational exposure to zoonotic agents among agricultural workers in Lombardy Region, Northern Italy," Annals of Agricultural and Environmental Medicine, vol. 20, no. 4, pp. 676-681, 2013.

[48] A. Krumbholz, U. Mohn, J. Lange et al., "Prevalence of hepatitis E virus-specific antibodies in humans with occupational exposure to pigs," Medical Microbiology and Immunology, vol. 201, no. 2, pp. 239-244, 2012.

[49] P. Dremsek, J. J. Wenzel, R. Johne et al., "Seroprevalence study in forestry workers from eastern Germany using novel genotype 3- and rat hepatitis E virus-specific immunoglobulin G ELISAs," Medical Microbiology and Immunology, vol. 201, no. 2, pp. 189200, 2012.

[50] A. Ceylan, M. Ertem, E. Ilcin, and T. Ozekinci, "A special risk group for hepatitis $\mathrm{E}$ infection: Turkish agricultural workers who use untreated waste water for irrigation," Epidemiology and Infection, vol. 131, no. 1, pp. 753-756, 2003.

[51] G. Scotto, B. Grisorio, P. Filippini et al., "Hepatitis E virus co-infection in HIV-infected patients in Foggia and Naples in southern Italy," Infectious Diseases, vol. 47, no. 10, pp. 707-713, 2015.

[52] M. Riveiro-Barciela, M. Buti, M. Homs et al., "Cirrhosis, liver transplantation and HIV infection are risk factors associated with hepatitis E virus infection," PLoS ONE, vol. 9, no. 7, Article ID e103028, 2014.

[53] M. F. Lopez-Fabal and J. L. Gomez-Garces, "Seroprevalence of hepatitis E virus in patients with hepatitis C and / or infected with HIV," Revista Española de Quimioterapia, vol. 28, no. 6, pp. 314-316, 2015.

[54] S. Pischke, A. Gisa, P. V. Suneetha et al., "Increased HEV seroprevalence in patients with autoimmune hepatitis," PLOS ONE, vol. 9, no. 1, Article ID e85330, 2014.

[55] G. Scotto, F. Aucella, G. Grandaliano et al., "Hepatitis E in hemodialysis and kidney transplant patients in South-East Italy," World Journal of Gastroenterology, vol. 21, no. 11, pp. 32663273, 2015.

[56] A. Harrison, L. Scobie, C. Crossan et al., "Hepatitis E seroprevalence in recipients of renal transplants or haemodialysis in southwest England: a case-control study," Journal of Medical Virology, vol. 85, no. 2, pp. 266-271, 2013.

[57] S. Pischke, P. Stiefel, B. Franz et al., "Chronic hepatitis e in heart transplant recipients," American Journal of Transplantation, vol. 12, no. 11, pp. 3128-3133, 2012.

[58] L. A. Kondili, P. Chionne, A. Porcaro et al., "Seroprevalence of hepatitis E virus (HEV) antibody and the possible association with chronic liver disease: a case-control study in Albania," Epidemiology and Infection, vol. 134, no. 1, pp. 95-101, 2006.

[59] I. M. Sayed, A.-S. Vercouter, S. F. Abdelwahab, K. Vercauteren, and P. Meuleman, "Is hepatitis E virus an emerging problem in industrialized countries?” Hepatology, vol. 62, no. 6, pp. 18831892, 2015.

[60] R. Bendall, V. Ellis, S. Ijaz, R. Ali, and H. Dalton, "A comparison of two commercially available anti-HEV IgG kits and a reevaluation of anti-HEV IgG seroprevalence data in developed countries," Journal of Medical Virology, vol. 82, no. 5, pp. 799805, 2010.

[61] A. Avellon, L. Morago, M. Garcia-Galera del Carmen, M. Munoz, and J.-M. Echevarría, "Comparative sensitivity of commercial tests for hepatitis E genotype 3 virus antibody detection," Journal of Medical Virology, vol. 87, no. 11, pp. 1934-1939, 2015.

[62] J. Hartl, B. Otto, R. Madden et al., "Hepatitis E seroprevalence in Europe: a meta-analysis," Viruses, vol. 8, no. 8, article 211, 2016.

[63] M. Rapicetta, L. A. Kondili, S. Pretolani et al., "Seroprevalence and anti-HEV persistence in the general population of the Republic of San Marino," Journal of Medical Virology, vol. 58, no. 1, pp. 49-53, 1999.

[64] R. Lopez-Izquierdo, M. Antonia Udaondo, P. Zarzosa et al., "Seroprevalencia de las hepatitis virales en población general representativa de una zona básica de salud urbana en Castilla y León," Enfermedades Infecciosas y Microbiología Clínica, vol. 25, no. 5, pp. 317-323, 2007 (Spanish).

[65] J. M. Mansuy, K. Saune, H. Rech et al., "Seroprevalence in blood donors reveals widespread, multi-source exposure to hepatitis E virus, southern France, October 2011," Eurosurveillance, vol. 20, no. 19, pp. 27-34, 2015. 
[66] B. M. Hogema, M. Molier, E. Slot, and H. L. Zaaijer, "Past and present of hepatitis e in the Netherlands," Transfusion, vol. 54, no. 12, pp. 3092-3096, 2014.

[67] J. M. Echevarría, M. Fogeda, and A. Avellón, "Diagnosis of acute hepatitis E by antibody and molecular testing: a study on 277 suspected cases," Journal of Clinical Virology, vol. 50, no. 1, pp. 69-71, 2011.

[68] H. Lagler, W. Poeppl, H. Winkler et al., "Hepatitis E virus seroprevalence in austrian adults: a nationwide cross-sectional study among civilians and military professionals," PLOS ONE, vol. 9, no. 2, Article ID e87669, 2014.

[69] I. Montes Martínez and A. Agulla Budiño, "Prevalence of antibodies against hepatitis $\mathrm{A}, \mathrm{B}, \mathrm{C}$ and $\mathrm{E}$ viruses in the rural child population in Northern Extremadura," Anales Espanoles de Pediatria, vol. 45, no. 2, pp. 133-136, 1996.

[70] M. Buti, P. Plans, A. Domínguez et al., "Prevalence of hepatitis E virus infection in children in the northeast of Spain," Clinical and Vaccine Immunology, vol. 15, no. 4, pp. 732-734, 2008.

[71] A. Krumbholz, A. Neubert, S. Joel et al., "Prevalence of hepatitis E virus antibodies in children in Germany," The Pediatric infectious disease journal, vol. 33, no. 3, pp. 258-262, 2014.

[72] M. L. Mateos, A. Molina, T. H. Ta, V. Moreira, J. M. Milicua, and R. Bárcena, "Acute hepatitis E in Madrid: description of 18 cases," Gastroenterología y Hepatología, vol. 29, no. 7, pp. 397400, 2006.

[73] J. Izopet, A. B. Labrique, B. Basnyat et al., "Hepatitis E virus seroprevalence in three hyperendemic areas: Nepal, Bangladesh and southwest France," Journal of Clinical Virology, vol. 70, pp. 39-42, 2015.

[74] T. Petrović, D. Lupulović, N. Jiménez de Oya et al., "Prevalence of hepatitis E virus (HEV) antibodies in Serbian blood donors," The Journal of Infection in Developing Countries, vol. 8, no. 10, pp. 1322-1327, 2014.

[75] H. R. Dalton, W. Stableforth, P. Thurairajah et al., "Autochthonous hepatitis e in Southwest England: natural history, complications and seasonal variation, and hepatitis e virus IgG seroprevalence in blood donors, the elderly and patients with chronic liver disease," European Journal of Gastroenterology and Hepatology, vol. 20, no. 8, pp. 784-790, 2008.

[76] H. R. Dalton, H. J. Fellows, W. Stableforth et al., "The role of hepatitis E virus testing in drug-induced liver injury," Alimentary Pharmacology \& Therapeutics, vol. 26, no. 10, pp. 1429-1435, 2007.

[77] M. Herremans, H. Vennema, J. Bakker et al., "Swine-like hepatitis $\mathrm{E}$ viruses are a cause of unexplained hepatitis in The Netherlands," Journal of Viral Hepatitis, vol. 14, no. 2, pp. 140146, 2007.

[78] K. Waar, M. M. P. T. Herremans, H. Vennema, M. P. G. Koopmans, and C. A. Benne, "Hepatitis $\mathrm{E}$ is a cause of unexplained hepatitis in the Netherlands," Journal of Clinical Virology, vol. 33, no. 2, pp. 145-149, 2005.

[79] M. T. Pérez-Gracia, M. S. García-Valdivia, F. Galán, and M. A. Rodríguez-Iglesias, "Detection of hepatitis E virus in patients sera in southern Spain," Acta Virologica, vol. 48, no. 3, pp. 197200, 2004.

[80] G. G. Schlauder, S. M. Desai, A. R. Zanetti, N. C. Tassopoulos, and I. K. Mushahwar, "Novel hepatitis E virus (HEV) isolates from Europe: evidence for additional genotypes of HEV," Journal of Medical Virology, vol. 57, no. 3, pp. 243-251, 1999.

[81] A. R. Zanetti, G. G. Schlauder, L. Romanò et al., "Identification of a novel variant of hepatitis E virus in Italy," Journal of Medical Virology, vol. 57, no. 4, pp. 356-360, 1999.
[82] H. C. Worn, G. G. Schlauder, H. Wurzer, and I. K. Mushahwar, "Identification of a novel variant of hepatitis E virus in Austria: sequence, phylogenetic and serological analysis," Journal of General Virology, vol. 81, no. 12, pp. 2885-2890, 2000.

[83] S. Pina, M. Buti, M. Cotrina, J. Piella, and R. Girones, "HEV identified in serum from humans with acute hepatitis and in sewage of animal origin in Spain," Journal of Hepatology, vol. 33, no. 5, pp. 826-833, 2000.

[84] J. M. Echevarría, M. Fogeda, and A. Avellón, "Update of cases of acute hepatitis E confirmed by the National Centre of Microbiology (Spain, 2004-2011)," Enfermedades Infecciosas y Microbiología Clínica, vol. 31, no. 1, pp. 57-58, 2013.

[85] M. Buti, P. Clemente-Casares, R. Jardi et al., "Sporadic cases of acute autochthonous hepatitis E in Spain," Journal of Hepatology, vol. 41, no. 1, pp. 126-131, 2004.

[86] F. Legrand-Abravanel, N. Kamar, K. Sandres-Saune et al., "Characteristics of autochthonous hepatitis e virus infection in solidorgan transplant recipients in France," Journal of Infectious Diseases, vol. 202, no. 6, pp. 835-844, 2010.

[87] M. Baymakova, B. Sakem, K. Plochev et al., "Epidemiological characteristics and clinical manifestations of hepatitis E virus infection in Bulgaria: a report on 20 patients," Srpski Arhiv za Celokupno Lekarstvo, vol. 144, no. 1-2, pp. 63-68, 2016.

[88] I. Kokki, D. Smith, P. Simmonds et al., "Hepatitis E virus is the leading cause of acute viral hepatitis in Lothian, Scotland," New Microbes and New Infections, vol. 10, pp. 6-12, 2016.

[89] P. Manka, L. P. Bechmann, J. D. Coombes et al., "Hepatitis E virus infection as a possible cause of acute liver failure in Europe," Clinical Gastroenterology and Hepatology, vol. 13, no. 10, pp. 1836-1842.e2, 2015.

[90] O. Wichmann, S. Schimanski, J. Koch et al., "Phylogenetic and case-control study on hepatitis E virus infection in Germany," Journal of Infectious Diseases, vol. 198, no. 12, pp. 1732-1741, 2008.

[91] G. L. Rosa, M. Muscillo, V. S. Vennarucci, A. R. Garbuglia, P. L. Scala, and M. R. Capobianchi, "Hepatitis E virus in Italy: molecular analysis of travel-related and autochthonous cases," Journal of General Virology, vol. 92, no. 7, pp. 1617-1626, 2011.

[92] G. La Rosa, M. Fratini, M. Muscillo et al., "Molecular characterisation of human hepatitis e virus from Italy: comparative analysis of five reverse transcription-PCR assays," Virology Journal, vol. 11, no. 1, article no. 72, 2014.

[93] H. Norder, L. Sundqvist, L. Magnusson et al., "Endemic hepatitis E in two Nordic countries," Eurosurveillance, vol. 14, no. 19, p. 19211, 2009.

[94] S. Tessé, B. Lioure, L. Fornecker et al., "Circulation of genotype 4 hepatitis E virus in Europe: first autochthonous hepatitis E infection in France," Journal of Clinical Virology, vol. 54, no. 2, pp. 197-200, 2012.

[95] A. Jeblaoui, S. Haim-Boukobza, E. Marchadier, C. Mokhtari, and A.-M. Roque-Afonso, "Genotype 4 hepatitis E virus in France: an autochthonous infection with a more severe presentation," Clinical Infectious Diseases, vol. 57, no. 4, pp. e122-e126, 2013.

[96] P. Colson, P. Romanet, V. Moal et al., "Autochthonous infections with hepatitis E virus genotype 4, France," Emerging Infectious Diseases, vol. 18, no. 8, pp. 1361-1364, 2012.

[97] A. R. Garbuglia, P. Scognamiglio, N. Petrosillo et al., "Hepatitis E virus genotype 4 outbreak, Italy, 2011," Emerging Infectious Diseases, vol. 19, no. 1, pp. 110-114, 2013. 
[98] S. Midgley, H. T. Vestergaard, C. Dalgaard, L. Enggaard, and T. K. Fischer, "Hepatitis E virus genotype 4, Denmark, 2012," Emerging Infectious Diseases, vol. 20, no. 1, pp. 156-157, 2014.

[99] L. Epelboin, E. Nicand, C. Roussin et al., "A sporadic case of genotype $3 \mathrm{f}$ acute hepatitis E in Mayotte," Médecine et Maladies Infectieuses, vol. 41, no. 7, pp. 392-394, 2011.

[100] M. Fogeda, A. Avellón, C. G. Cilla, and J. M. Echevarría, "Imported and autochthonous hepatitis $\mathrm{E}$ virus strains in Spain," Journal of Medical Virology, vol. 81, no. 10, pp. 1743-1749, 2009.

[101] K. J. Rolfe, M. D. Curran, N. Mangrolia et al., "First case of genotype 4 human hepatitis E virus infection acquired in India," Journal of Clinical Virology, vol. 48, no. 1, pp. 58-61, 2010.

[102] M. L. Mateos, A. Molina, J. L. Patier, and V. Moreira, "Sporadic hepatitis E in Spain: study of 9 autochthonous and 3 imported cases," Medicina Clinica, vol. 125, no. 3, pp. 118-119, 2005.

[103] M. L. Mateos Lindemann, J. G. Morales, S. Fernández-Barredo et al., "Fulminant hepatitis E in a woman taking oral contraceptive medication," The American Journal of Tropical Medicine and Hygiene, vol. 82, no. 1, pp. 12-15, 2010.

[104] M. L. Mateos-Lindemann, M. Diez-Aguilar, A. González-Galdamez, J. Graus-Morales, A. Moreno-Zamora, and M. T. PerezGracia, "Acute, chronic and fulminant hepatitisE: seven years of experience (2004-2011)," Enfermedades Infecciosas y Microbiología Clínica, vol. 31, no. 9, pp. 595-598, 2013.

[105] S. Festa, A. R. Garbuglia, F. Baccini et al., "Acute fulminant hepatitis E virus genotype $3 e$ infection: description of the first case in Europe," Scandinavian Journal of Infectious Diseases, vol. 46, no. 10, pp. 727-731, 2014.

[106] B. Doudier, D. Verrot, C. Serratrice, C. Poucel, R. Auguste, and P. Colson, "Fatal outcome of autochthonous hepatitis $\mathrm{E}$ in a patient with B cell lymphoma in Southeastern France," Journal of Clinical Microbiology, vol. 53, no. 1, pp. 339-342, 2015.

[107] S. Aherfi, P. Borentain, F. Raissouni et al., "Liver transplantation for acute liver failure related to autochthonous genotype 3 hepatitis E virus infection," Clinics and Research in Hepatology and Gastroenterology, vol. 38, no. 1, pp. 24-31, 2014.

[108] S. Ijaz, E. Arnold, M. Banks et al., "Non-travel-associated hepatitis E in England and Wales: demographic, clinical, and molecular epidemiological characteristics," Journal of Infectious Diseases, vol. 192, no. 7, pp. 1166-1172, 2005.

[109] P. Chalupa, P. Vasickova, I. Pavlik, and M. Holub, "Endemic hepatitis e in the Czech Republic," Clinical Infectious Diseases, vol. 58, no. 4, pp. 509-516, 2014.

[110] B. Doudier, H. Vencatassin, S. Aherfi, and P. Colson, "Fatal fulminant hepatitis $\mathrm{E}$ associated with autoimmune hepatitis and excessive paracetamol intake in Southeastern France," Journal of Clinical Microbiology, vol. 52, no. 4, pp. 1294-1297, 2014.

[111] H. R. Dalton, R. P. Bendall, F. E. Keane, R. S. Tedder, and S. Ijaz, "Persistent carriage of hepatitis E virus in patients with HIV infection," The New England Journal of Medicine, vol. 361, no. 10, pp. 1025-1027, 2009.

[112] G. K. Jagjit Singh, S. Ijaz, N. Rockwood et al., "Chronic Hepatitis $\mathrm{E}$ as a cause for cryptogenic cirrhosis in HIV," Journal of Infection, vol. 66, no. 1, pp. 103-106, 2013.

[113] H. R. Dalton, F. E. Keane, R. Bendall, J. Mathew, and S. Ijaz, "Treatment of chronic Hepatitis E in a patient with HIV infection," Annals of Internal Medicine, vol. 155, no. 7, pp. 479480, 2011.

[114] K. Neukam, P. Barreiro, J. Macías et al., "Chronic hepatitis e in HIV patients: rapid progression to cirrhosis and response to oral ribavirin," Clinical Infectious Diseases, vol. 57, no. 3, pp. 465468, 2013.

[115] P. Colson, C. Dhiver, I. Poizot-Martin, C. Tamalet, and R. Gérolami, "Acute and chronic hepatitis E in patients infected with human immunodeficiency virus," Journal of Viral Hepatitis, vol. 18, no. 3, pp. 227-228, 2011.

[116] V. Moal, J. Textoris, A. B. Amara et al., "Chronic hepatitis Evirus infection is specifically associated with an interferon-related transcriptional program," The Journal of Infectious Diseases, vol. 207, no. 1, pp. 125-132, 2013.

[117] A. De Niet, H. L. Zaaijer, I. Ten Berge, C. J. Weegink, H. W. Reesink, and U. Beuers, "Chronic hepatitis E after solid organ transplantation," Netherlands Journal of Medicine, vol. 70, no. 6, pp. 261-266, 2012.

[118] P. V. Suneetha, S. Pischke, V. Schlaphoff et al., "Hepatitis E virus (HEV)-specific T-cell responses are associated with control of HEV infection," Hepatology, vol. 55, no. 3, pp. 695-708, 2012.

[119] N. Kamar, L. Rostaing, F. Abravanel et al., "Ribavirin therapy inhibits viral replication on patients with chronic hepatitis e virus infection," Gastroenterology, vol. 139, no. 5, pp. 1612-1618, 2010.

[120] E. B. Haagsma, A. Riezebos-Brilman, A. P. Van Den Berg, R. J. Porte, and H. G. M. Niesters, "Treatment of chronic hepatitis $\mathrm{E}$ in liver transplant recipients with pegylated interferon alpha2b," Liver Transplantation, vol. 16, no. 4, pp. 474-477, 2010.

[121] S. Pischke, P. V. Suneetha, C. Baechlein et al., "Hepatitis E virus infection as a cause of graft hepatitis in liver transplant recipients," Liver Transplantation, vol. 16, no. 1, pp. 74-82, 2010.

[122] A. Riezebos-Brilman, E. Puchhammer-Stöckl, H. Y. Van Der Weide et al., "Chronic hepatitis e infection in lung transplant recipients," Journal of Heart and Lung Transplantation, vol. 32, no. 3, pp. 341-346, 2013.

[123] S. Pischke, M. Greer, S. Hardtke et al., "Course and treatment of chronic hepatitis E virus infection in lung transplant recipients," Transplant Infectious Disease, vol. 16, no. 2, pp. 333-339, 2014.

[124] S. D. Pas, R. A. de Man, C. Mulders et al., "Hepatitis E virus infection among solid organ transplant recipients, The Netherlands," Emerging Infectious Diseases, vol. 18, no. 5, pp. 869-872, 2012.

[125] A. H. M. Bouts, P. J. Schriemer, and H. L. Zaaijer, "Chronic hepatitis $\mathrm{E}$ resolved by reduced immunosuppression in pediatric kidney transplant patients," Pediatrics, vol. 135, no. 4, pp. e1075e1078, 2015.

[126] A. Riezebos-Brilman, E. A. M. Verschuuren, W. J. van Son et al., "The clinical course of hepatitis E virus infection in patients of a tertiary Dutch hospital over a 5-year period," Journal of Clinical Virology, vol. 58, no. 3, pp. 509-514, 2013.

[127] A. Gauss, J. J. Wenzel, C. Flechtenmacher et al., "Chronic hepatitis $\mathrm{E}$ virus infection in a patient with leukemia and elevated transaminases: a case report," Journal of Medical Case Reports, vol. 6, article 334, 2012.

[128] U. Halac, K. Béland, P. Lapierre et al., "Cirrhosis due to chronic hepatitis e infection in a child post-bone marrow transplant," Journal of Pediatrics, vol. 160, no. 5, pp. 871-874.el, 2012.

[129] L. Alric, D. Bonnet, O. Beynes-Rauzy, J. Izopet, and N. Kamar, "Definitive clearance of a chronic hepatitis E virus infection with ribavirin treatment," The American Journal of Gastroenterology, vol. 106, no. 8, pp. 1562-1563, 2011.

[130] S. Tavitian, J.-M. Péron, A. Huynh et al., "Hepatitis E virus excretion can be prolonged in patients with hematological malignancies," Journal of Clinical Virology, vol. 49, no. 2, pp. 141$144,2010$. 
[131] S. Tavitian, J.-M. Peron, F. Huguet et al., "Ribavirin for chronic hepatitis prevention among patients with hematologic malignancies," Emerging Infectious Diseases, vol. 21, no. 8, pp. 14661469, 2015.

[132] Y. Geng, H. Zhang, W. Huang et al., "Persistent hepatitis e virus genotype 4 infection in a child with acute lymphoblastic leukemia," Hepatitis Monthly, vol. 14, no. 1, Article ID e15618, 2014.

[133] A. I. Gonzalez Tallon, V. M. Vicente, M. L. M. Lindemann, and L. M. A. Justo, "Chronic hepatitis E in an immunocompetent patient," Journal of Gastroenterology and Hepatology, vol. 34, no. 6, pp. 398-400, 2011.

[134] B. van den Berg, A. A. van der Eijk, S. D. Pas et al., "GuillainBarré syndrome associated with preceding hepatitis E virus infection," Neurology, vol. 82, no. 6, pp. 491-497, 2014.

[135] J. J. J. Van Eijk, R. G. Madden, A. A. Van Der Eijk et al., "Neuralgic amyotrophy and hepatitis E virus infection," Neurology, vol. 82, no. 6, pp. 498-503, 2014.

[136] A. Motte, J. Franques, T. Weitten, and B. Colson, "Hepatitis E-associated Parsonage-Turner syndrome, France," Clinics and Research in Hepatology and Gastroenterology, vol. 38, no. 1, pp. el1-e14, 2014.

[137] A. Dartevel, B. Colombe, A. Bosseray et al., "Hepatitis E and neuralgic amyotrophy: five cases and review of literature," Journal of Clinical Virology, vol. 69, pp. 156-164, 2015.

[138] A. M. Peri, L. Milazzo, L. Meroni, and S. Antinori, "Radiculoneuropathy associated with acute hepatitis E," Digestive and Liver Disease, vol. 45, no. 11, pp. 963-964, 2013.

[139] N. Scharn, T. Ganzenmueller, J. J. Wenzel, R. Dengler, A. Heim, and F. Wegner, "Guillain-Barré syndrome associated with autochthonous infection by hepatitis E virus subgenotype 3c," Infection, vol. 42, no. 1, pp. 171-173, 2014.

[140] X. J. Meng, R. H. Purcell, P. G. Halbur et al., "A novel virus in swine is closely related to the human hepatitis E virus," Proceedings of the National Academy of Sciences of the United States of America, vol. 94, no. 18, pp. 9860-9865, 1997.

[141] V. Doceul, E. Bagdassarian, A. Demange, and N. Pavio, “Zoonotic hepatitis E virus: classification, animal reservoirs and transmission routes," Viruses, vol. 8, no. 10, article 270, 2016.

[142] W. H. Van der Poel, "Food and environmental routes of Hepatitis E virus transmission," Current Opinion in Virology, vol. 4, pp. 91-96, 2014.

[143] M. Casas, J. Pujols, R. Rosell et al., "Retrospective serological study on hepatitis E infection in pigs from 1985 to 1997 in Spain," Veterinary Microbiology, vol. 135, no. 3-4, pp. 248-252, 2009.

[144] C. Seminati, E. Mateu, B. Peralta, N. de Deus, and M. Martin, "Distribution of hepatitis E virus infection and its prevalence in pigs on commercial farms in Spain," Veterinary Journal, vol. 175, no. 1, pp. 130-132, 2008.

[145] N. Costanzo, E. Sarno, V. Peretti, L. Ciambrone, F. Casalinuovo, and A. Santoro, "Serological and molecular investigation of swine hepatitis E virus in pigs raised in southern Italy," Journal of Food Protection, vol. 78, no. 11, pp. 2099-2102, 2015.

[146] I. Di Bartolo, E. Ponterio, L. Castellini, F. Ostanello, and F. M. Ruggeri, "Viral and antibody HEV prevalence in swine at slaughterhouse in Italy," Veterinary Microbiology, vol. 149, no. 34, pp. 330-338, 2011.

[147] F. Jori, M. Laval, O. Maestrini, F. Casabianca, F. Charrier, and N. Pavio, "Assessment of domestic pigs, wild boars and feral hybrid pigs as reservoirs of hepatitis E virus in Corsica, France," Viruses, vol. 8, no. 8, 2016.
[148] S. Ø. Breum, C. K. Hjulsager, N. de Deus, J. Segalés, and L. E. Larsen, "Hepatitis E virus is highly prevalent in the Danish pig population," Veterinary Microbiology, vol. 146, no. 1-2, pp. 144149,2010

[149] S. Grierson, J. Heaney, T. Cheney et al., "Prevalence of hepatitis E virus infection in pigs at the time of slaughter, United Kingdom, 2013," Emerging Infectious Diseases, vol. 21, no. 8, pp. 1396-1401, 2015.

[150] C. Crossan, S. Grierson, J. Thomson et al., "Prevalence of hepatitis E virus in slaughter-age pigs in Scotland," Epidemiology and Infection, vol. 143, no. 10, pp. 2237-2240, 2015.

[151] A. Ivanova, V. Tefanova, I. Reshetnjak et al., "Hepatitis E virus in domestic pigs, wild boars, pig farm workers, and hunters in estonia," Food and Environmental Virology, vol. 7, no. 4, pp. 403412, 2015.

[152] A. Krumbholz, S. Joel, P. Dremsek et al., "Seroprevalence of hepatitis E virus (HEV) in humans living in high pig density areas of Germany," Medical Microbiology and Immunology, vol. 203, no. 4, pp. 273-282, 2014.

[153] P. Dremsek, S. Joel, C. Baechlein et al., "Hepatitis E virus seroprevalence of domestic pigs in Germany determined by a novel in-house and two reference ELISAs," Journal of Virological Methods, vol. 190, no. 1-2, pp. 11-16, 2013.

[154] S. Wacheck, E. Sarno, E. Märtlbauer, C. Zweifel, and R. Stephan, "Seroprevalence of anti-hepatitis E virus and anti-salmonella antibodies in pigs at slaughter in Switzerland," Journal of Food Protection, vol. 75, no. 8, pp. 1483-1485, 2012.

[155] S. Wacheck, C. Werres, U. Mohn et al., "Detection of IgM and IgG against hepatitis $\mathrm{E}$ virus in serum and meat juice samples from pigs at slaughter in Bavaria, Germany," Foodborne Pathogens and Disease, vol. 9, no. 7, pp. 655-660, 2012.

[156] S. Fernández-Barredo, C. Galiana, A. García et al., "Prevalence and genetic characterization of hepatitis E virus in paired samples of feces and serum from naturally infected pigs," Canadian Journal of Veterinary Research, vol. 71, no. 3, pp. 236240, 2007.

[157] N. Jiménez De Oya, I. De Blas, A.-B. Blázquez et al., "Widespread distribution of hepatitis e virus in Spanish pig herds," BMC Research Notes, vol. 4, article 412, 2011.

[158] C. Baechlein, A. Schielke, R. Johne, R. G. Ulrich, W. Baumgaertner, and B. Grummer, "Prevalence of Hepatitis E virus-specific antibodies in sera of German domestic pigs estimated by using different assays," Veterinary Microbiology, vol. 144, no. 1-2, pp. 187-191, 2010.

[159] S. Fernández-Barredo, C. Galiana, A. García, S. Vega, M. T. Gómez, and M. T. Pérez-Gracia, "Detection of hepatitis E virus shedding in feces of pigs at different stages of production using reverse transcription-polymerase chain reaction," Journal of Veterinary Diagnostic Investigation, vol. 18, no. 5, pp. 462-465, 2006.

[160] M. Casas, R. Cortés, S. Pina et al., "Longitudinal study of hepatitis E virus infection in Spanish farrow-to-finish swine herds," Veterinary Microbiology, vol. 148, no. 1, pp. 27-34, 2011.

[161] C. Kasorndorkbua, B. J. Thacker, P. G. Halbur et al., "Experimental infection of pregnant gilts with swine hepatitis E virus," Canadian Journal of Veterinary Research, vol. 67, no. 4, pp. 303306, 2003.

[162] M. Monini, I. Di Bartolo, G. Ianiro et al., "Detection and molecular characterization of zoonotic viruses in swine fecal samples in Italian pig herds," Archives of Virology, vol. 160, no. 10, pp. 2547-2556, 2015. 
[163] P. G. Halbur, C. Kasorndorkbua, C. Gilbert et al., "Comparative pathogenesis of infection of pigs with hepatitis $\mathrm{E}$ viruses recovered from a pig and a human," Journal of Clinical Microbiology, vol. 39, no. 3, pp. 918-923, 2001.

[164] C. McCreary, F. Martelli, S. Grierson, F. Ostanello, A. Nevel, and M. Banks, "Excretion of hepatitis E virus by pigs of different ages and its presence in slurry stores in the United Kingdom," Veterinary Record, vol. 163, no. 9, pp. 261-265, 2008.

[165] D. Kukielka, V. Rodriguez-Prieto, J. Vicente, and J. M. SánchezVizcaíno, "Constant hepatitis E virus (HEV) circulation in wild boar and red deer in Spain: an increasing concern source of HEV zoonotic transmission," Transboundary and Emerging Diseases, vol. 63, no. 5, pp. e360-e368, 2016.

[166] N. de Deus, B. Peralta, S. Pina et al., "Epidemiological study of hepatitis E virus infection in European wild boars (Sus scrofa) in Spain," Veterinary Microbiology, vol. 129, no. 1-2, pp. 163-170, 2008.

[167] M. Boadella, J. F. Ruiz-Fons, J. Vicente, M. Martín, J. Segalés, and C. Gortazar, "Seroprevalence evolution of selected pathogens in iberian wild boar," Transboundary and Emerging Diseases, vol. 59, no. 5, pp. 395-404, 2012.

[168] S. Montagnaro, C. De Martinis, S. Sasso et al., "Viral and antibody prevalence of hepatitis E in European wild boars (Sus scrofa) and hunters at Zoonotic risk in the Latium Region," Journal of Comparative Pathology, vol. 153, no. 1, pp. 1-8, 2015.

[169] A. Schielke, K. Sachs, M. Lierz, B. Appel, A. Jansen, and R. Johne, "Detection of hepatitis E virus in wild boars of rural and urban regions in Germany and whole genome characterization of an endemic strain," Virology Journal, vol. 6, article 58, 2009.

[170] D. Thiry, A. Mauroy, C. Saegerman et al., "Belgian wildlife as potential zoonotic reservoir of hepatitis E virus," Transboundary and Emerging Diseases, 2015.

[171] M. Larska, M. K. Krzysiak, A. Jabłoński, J. Kesik, M. Bednarski, and J. Rola, "Hepatitis E virus antibody prevalence in wildlife in Poland," Zoonoses and Public Health, vol. 62, no. 2, pp. 105-110, 2015.

[172] M. Boadella, M. Casas, M. Martín et al., "Increasing contact with hepatitis E virus in red deer, Spain," Emerging Infectious Diseases, vol. 16, no. 12, pp. 1994-1996, 2010.

[173] S. Neumann, S. S. Hackl, M. Piepenschneider et al., "Serologic and molecular survey of hepatitis E virus in German deer populations," Journal of Wildlife Diseases, vol. 52, no. 1, pp. 106113, 2016.

[174] S. A. Rutjes, F. Lodder-Verschoor, W. J. Lodder et al., "Seroprevalence and molecular detection of hepatitis E virus in wild boar and red deer in The Netherlands," Journal of Virological Methods, vol. 168, no. 1-2, pp. 197-206, 2010.

[175] A. Roth, J. Lin, L. Magnius et al., "Markers for ongoing or previous hepatitis $\mathrm{E}$ virus infection are as common in wild ungulates as in humans in Sweden," Viruses, vol. 8, no. 9, p. 259, 2016.

[176] I. Di Bartolo, M. Diez-Valcarce, P. Vasickova et al., "Hepatitis E virus in pork production chain in Czech Republic, Italy, and Spain, 2010," Emerging Infectious Diseases, vol. 18, no. 8, pp. 1282-1289, 2012.

[177] A. Vina-Rodriguez, J. Schlosser, D. Becher, V. Kaden, M. H. Groschup, and M. Eiden, "Hepatitis E virus genotype 3 diversity: phylogenetic analysis and presence of subtype $3 \mathrm{~b}$ in wild boar in Europe," Viruses, vol. 7, no. 5, pp. 2704-2726, 2015.

[178] T. Kantala, M. Heinonen, S. Oristo, C.-H. Von Bonsdorff, and L. Maunula, "Hepatitis E virus in young pigs in finland and characterization of the isolated partial genomic sequences of genotype 3 HEV," Foodborne Pathogens and Disease, vol. 12, no. 3, pp. 253-260, 2015.

[179] R. W. H. van der Honing, E. van Coillie, A. F. G. Antonis, and W. H. M. van der Poel, "First isolation of hepatitis E virus genotype 4 in Europe through Swine surveillance in the Netherlands and Belgium," PLoS ONE, vol. 6, no. 8, Article ID e22673, 2011.

[180] I. Monne, L. Ceglie, G. Di Martino et al., "Hepatitis E virus genotype 4 in a pig farm, Italy, 2013," Epidemiology and Infection, vol. 143, no. 3, pp. 529-533, 2015.

[181] P. Clemente-Casares, S. Pina, M. Buti et al., "Hepatitis E virus epidemiology in industrialized countries," Emerging Infectious Diseases, vol. 9, no. 4, pp. 448-454, 2003.

[182] I. Di Bartolo, L. De Sabato, A. Marata et al., "Serological survey of hepatitis E virus infection in farmed and pet rabbits in Italy," Archives of Virology, vol. 161, no. 5, pp. 1343-1346, 2016.

[183] J. Izopet, M. Dubois, S. Bertagnoli et al., "Hepatitis E virus strains in rabbits and evidence of a closely related strain in humans, France," Emerging Infectious Diseases, vol. 18, no. 8, pp. 1274-1281, 2012.

[184] M. Eiden, A. Vina-Rodriguez, J. Schlosser, H. Schirrmeier, and M. H. Groschup, "Detection of hepatitis E virus in archived rabbit serum samples, Germany 1989," Food and Environmental Virology, vol. 8, no. 1, pp. 105-107, 2016.

[185] S. A. Burt, J. Veltman, R. Hakze-van der Honing, H. Schmitt, and W. H. van der Poel, "Hepatitis E virus in farmed rabbits, wild rabbits and petting farm rabbits in the Netherlands," Food and Environmental Virology, vol. 8, no. 3, pp. 227-229, 2016.

[186] C. Caruso, P. Modesto, R. Prato et al., "Hepatitis E virus: first description in a pet house rabbit. A new transmission route for human?" Transboundary and Emerging Diseases, vol. 62, no. 3, pp. 229-232, 2015.

[187] B. Di Martino, F. Di Profio, I. Melegari et al., "Detection of hepatitis E virus (HEV) in goats," Virus Research, vol. 225, pp. 69-72, 2016.

[188] B. Peralta, M. Casas, N. de Deus et al., "Anti-HEV antibodies in domestic animal species and rodents from Spain using a genotype 3-based ELISA," Veterinary Microbiology, vol. 137, no. 1-2, pp. 66-73, 2009.

[189] A. McElroy, R. Hiraide, N. Bexfield et al., "Detection of hepatitis E virus antibodies in dogs in the United Kingdom," PLoS ONE, vol. 10, no. 6, Article ID e0128703, 2015.

[190] R. Johne, P. Dremsek, E. Kindler et al., "Rat hepatitis E virus: geographical clustering within Germany and serological detection in wild Norway rats (Rattus norvegicus)," Infection, Genetics and Evolution, vol. 12, no. 5, pp. 947-956, 2012.

[191] S. Wolf, J. Reetz, R. Johne et al., "The simultaneous occurrence of human norovirus and hepatitis E virus in a Norway rat (Rattus norvegicus)," Archives of Virology, vol. 158, no. 7, pp. 1575-1578, 2013.

[192] V. Stalin Raj, S. L. Smits, S. D. Pas et al., "Novel hepatitis E virus in ferrets, the Netherlands," Emerging Infectious Diseases, vol. 18, no. 8, pp. 1369-1370, 2012.

[193] A. Marek, I. Bilic, I. Prokofieva, and M. Hess, "Phylogenetic analysis of avian hepatitis E virus samples from European and Australian chicken flocks supports the existence of a different genus within the Hepeviridae comprising at least three different genotypes," Veterinary Microbiology, vol. 145, no. 1-2, pp. 54-61, 2010.

[194] B. Peralta, M. Biarnés, G. Ordóñez et al., "Evidence of widespread infection of avian hepatitis $\mathrm{E}$ virus (avian HEV) in 
chickens from Spain," Veterinary Microbiology, vol. 137, no. 1-2, pp. 31-36, 2009.

[195] G. Reuter, Á. Boros, R. Mátics, B. Kapusinszky, E. Delwart, and P. Pankovics, "Divergent hepatitis E virus in birds of prey, common kestrel (Falco tinnunculus) and red-footed falcon (F. vespertinus), Hungary," Infection, Genetics and Evolution, vol. 43, pp. 343-346, 2016.

[196] X. Li, S. Kamili, and K. Krawczynski, "Quantitative detection of hepatitis E virus RNA and dynamics of viral replication in experimental infection," Journal of Viral Hepatitis, vol. 13, no. 12, pp. 835-839, 2006.

[197] C. Kasorndorkbua, D. K. Guenette, F. F. Huang, P. J. Thomas, X.-J. Meng, and P. G. Halbur, "Routes of transmission of swine hepatitis E virus in pigs," Journal of Clinical Microbiology, vol. 42, no. 11, pp. 5047-5052, 2004.

[198] Y. Geng, C. Zhao, W. Huang et al., "Detection and assessment of infectivity of hepatitis E virus in urine," Journal of Hepatology, vol. 64, no. 1, pp. 37-43, 2016.

[199] S. Pina, J. Jofre, S. U. Emerson, R. H. Purcell, and R. Girones, "Characterization of a strain of infectious hepatitis E virus isolated from sewage in an area where hepatitis $\mathrm{E}$ is not endemic," Applied and Environmental Microbiology, vol. 64, no. 11, pp. 4485-4488, 1998.

[200] S. Bofill-Mas, N. Albinana-Gimenez, P. Clemente-Casares et al., "Quantification and stability of human adenoviruses and polyomavirus JCPyV in wastewater matrices," Applied and Environmental Microbiology, vol. 72, no. 12, pp. 7894-7896, 2006.

[201] J. Rodriguez-Manzano, M. Miagostovich, A. Hundesa et al., "Analysis of the evolution in the circulation of HAV and HEV in Eastern Spain by testing urban sewage samples," Journal of Water and Health, vol. 8, no. 2, pp. 346-354, 2010.

[202] V. La Fauci, D. Sindoni, O. C. Grillo, S. Calimeri, D. Lo Giudice, and R. Squeri, "Hepatitis E virus (HEV) in sewage from treatment plants of Messina University Hospital and of Messina city council," Journal of Preventive Medicine and Hygiene, vol. 51, no. 1, pp. 28-30, 2010.

[203] G. La Rosa, M. Pourshaban, M. Iaconelli, V. S. Vennarucci, and M. Muscillo, "Molecular detection of hepatitis E virus in sewage samples," Applied and Environmental Microbiology, vol. 76, no. 17, pp. 5870-5873, 2010.

[204] T. Miura, S. Lhomme, J. Le Saux et al., "Detection of hepatitis E virus in sewage after an outbreak on a French Island," Food and Environmental Virology, vol. 8, no. 3, pp. 194-199, 2016.

[205] M. Myrmel, H. Lange, and E. Rimstad, "A 1-year quantitative survey of noro-, adeno-, human boca-, and hepatitis e viruses in raw and secondarily treated sewage from two plants in Norway," Food and Environmental Virology, vol. 7, no. 3, pp. 213-223, 2015.

[206] M. Rusiñol, X. Fernandez-Cassi, N. Timoneda et al., "Evidence of viral dissemination and seasonality in a Mediterranean river catchment: implications for water pollution management," Journal of Environmental Management, vol. 159, pp. 58-67, 2015.

[207] N. Albinana-Gimenez, P. Clemente-Casares, S. Bofill-Mas, A. Hundesa, F. Ribas, and R. Girones, "Distribution of human polyomaviruses, adenoviruses, and hepatitis $\mathrm{E}$ virus in the environment and in a drinking-water treatment plant," Environmental Science and Technology, vol. 40, no. 23, pp. 7416-7422, 2006.

[208] P. Clemente-Casares, J. Rodriguez-Manzano, and R. Girones, "Hepatitis E virus genotype 3 and sporadically also genotype 1 circulate in the population of Catalonia, Spain," Journal of Water and Health, vol. 7, no. 4, pp. 664-673, 2009.
[209] P. Kokkinos, I. Kozyra, S. Lazic et al., "Virological quality of irrigation water in leafy green vegetables and berry fruits production chains," Food and Environmental Virology, pp. 1-7, 2016.

[210] P. Kokkinos, I. Kozyra, S. Lazic et al., "Harmonised investigation of the occurrence of human enteric viruses in the leafy green vegetable supply chain in three European countries," Food and Environmental Virology, vol. 4, no. 4, pp. 179-191, 2012.

[211] L. Maunula, A. Kaupke, P. Vasickova et al., "Tracing enteric viruses in the European berry fruit supply chain," International Journal of Food Microbiology, vol. 167, no. 2, pp. 177-185, 2013.

[212] C. Renou, X. Moreau, A. Pariente et al., "A national survey of acute hepatitis E in France," Alimentary Pharmacology \& Therapeutics, vol. 27, no. 11, pp. 1086-1093, 2008.

[213] A. Steyer, T. Naglič, T. Močilnik, M. Poljšak-Prijatelj, and M. Poljak, "Hepatitis E virus in domestic pigs and surface waters in Slovenia: prevalence and molecular characterization of a novel genotype 3 lineage," Infection, Genetics and Evolution, vol. 11, no. 7, pp. 1732-1737, 2011.

[214] M. Iaconelli, G. Purpari, S. D. Libera et al., "Hepatitis A and E viruses in wastewaters, in river waters, and in Bivalve Molluscs in Italy," Food and Environmental Virology, vol. 7, no. 4, pp. 316324, 2015.

[215] S. A. Rutjes, W. J. Lodder, F. Lodder-Verschoor et al., "Sources of hepatitis E virus genotype 3 in the Netherlands," Emerging Infectious Diseases, vol. 15, no. 3, pp. 381-387, 2009.

[216] K. Borgen, T. Herremans, E. Duizer et al., "Non-travel related Hepatitis E virus genotype 3 infections in the Netherlands; a case series 2004-2006," BMC Infectious Diseases, vol. 8, article 61, 2008.

[217] M. García, S. Fernández-Barredo, and M. T. Pérez-Gracia, "Detection of hepatitis E virus (HEV) through the different stages of pig manure composting plants," Microbial Biotechnology, vol. 7, no. 1, pp. 26-31, 2014.

[218] H. Krog, "Parmelina Enormis (Hale) Hale is Bulbothrix Enormis (Hale) Krog Comb. Nov,” The Lichenologist, vol. 25, no. 3, pp. 299-306, 1993.

[219] J. C. Heaton and K. Jones, "Microbial contamination of fruit and vegetables and the behaviour of enteropathogens in the phyllosphere: a review," Journal of Applied Microbiology, vol. 104, no. 3, pp. 613-626, 2008.

[220] D. M. Yugo and X.-J. Meng, "Hepatitis E virus: foodborne, waterborne and zoonotic transmission," International Journal of Environmental Research and Public Health, vol. 10, no. 10, pp. 4507-4533, 2013.

[221] C. Renou, A.-M. R. Afonso, and N. Pavio, "Foodborne transmission of hepatitis E virus from raw pork liver Sausage, France," Emerging Infectious Diseases, vol. 20, no. 11, pp. 1945-1947, 2014.

[222] M. Riveiro-Barciela, B. Mínguez, R. Gironés, F. RodriguezFrías, J. Quer, and M. Buti, "Phylogenetic demonstration of hepatitis E infection transmitted by pork meat ingestion," Journal of Clinical Gastroenterology, vol. 49, no. 2, pp. 165-168, 2015.

[223] P. Colson, P. Borentain, B. Queyriaux et al., "Pig liver sausage as a source of hepatitis e virus transmission to humans," Journal of Infectious Diseases, vol. 202, no. 6, pp. 825-834, 2010.

[224] Y. Guillois, F. Abravanel, T. Miura et al., "High proportion of asymptomatic infections in an outbreak of hepatitis e associated with a spit-roasted piglet, France, 2013," Clinical Infectious Diseases, vol. 62, no. 3, pp. 351-357, 2016.

[225] T. P. E. Williams, C. Kasorndorkbua, P. G. Halbur et al., "Evidence of extrahepatic sites of replication of the hepatitis $\mathrm{E}$ virus 
in a swine model," Journal of Clinical Microbiology, vol. 39, no. 9, pp. 3040-3046, 2001.

[226] M. Bouwknegt, F. Lodder-Verschoor, W. H. M. Van Der Poel, S. A. Rutjes, and A. M. D. R. Husman, "Hepatitis E virus RNA in commercial porcine livers in The Netherlands," Journal of Food Protection, vol. 70, no. 12, pp. 2889-2895, 2007.

[227] S. Martin-Latil, C. Hennechart-Collette, L. Guillier, and S. Perelle, "Method for HEV detection in raw pig liver products and its implementation for naturally contaminated food," International Journal of Food Microbiology, vol. 176, pp. 1-8, 2014.

[228] K. Szabo, E. Trojnar, H. Anheyer-Behmenburg et al., "Detection of hepatitis E virus RNA in raw sausages and liver sausages from retail in Germany using an optimized method," International Journal of Food Microbiology, vol. 215, pp. 149-156, 2015.

[229] D. Rodríguez-Lázaro, M. Diez-Valcarce, R. Montes-Briones, D. Gallego, M. Hernández, and J. Rovira, "Presence of pathogenic enteric viruses in illegally imported meat and meat products to EU by international air travelers," International Journal of Food Microbiology, vol. 209, pp. 39-43, 2015.

[230] N. Nantel-Fortier, A. Letellier, V. Lachapelle, P. Fravalo, Y. L'Homme, and J. Brassard, "Detection and phylogenetic analysis of the hepatitis $\mathrm{E}$ virus in a Canadian swine production network," Food and Environmental Virology, vol. 8, no. 4, pp. 296304, 2016.

[231] M. Diez-Valcarce, P. Kokkinos, K. Söderberg et al., "Occurrence of human enteric viruses in commercial mussels at retail level in three European countries," Food and Environmental Virology, vol. 4, no. 2, pp. 73-80, 2012.

[232] F. Loisy, R. L. Atmar, P. Guillon, P. Le Cann, M. Pommepuy, and F. S. Le Guyader, "Real-time RT-PCR for norovirus screening in shellfish," Journal of Virological Methods, vol. 123, no. 1, pp. 1-7, 2005.

[233] J. R. Mesquita, D. Oliveira, E. Rivadulla et al., "Hepatitis E virus genotype 3 in mussels (Mytilus galloprovinciallis), Spain," Food Microbiology, vol. 58, pp. 13-15, 2016.

[234] C. Crossan, P. J. Baker, J. Craft, Y. Takeuchi, H. R. Dalton, and L. Scobie, "Hepatitis E virus genotype 3 in shellfi sh, United Kingdom," Emerging Infectious Diseases, vol. 18, no. 12, pp. 2085-2087, 2012.

[235] A. Namsai, S. Louisirirotchanakul, N. Wongchinda et al., "Surveillance of hepatitis $A$ and $E$ viruses contamination in shellfish in Thailand," Letters in Applied Microbiology, vol. 53, no. 6, pp. 608-613, 2011.

[236] T. Kantala, L. Maunula, C.-H. von Bonsdorff, J. Peltomaa, and M. Lappalainen, "Hepatitis E virus in patients with unexplained hepatitis in Finland," Journal of Clinical Virology, vol. 45, no. 2, pp. 109-113, 2009.

[237] C. Galiana, S. Fernández-Barredo, A. García, M. T. Gómez, and M. T. Pérez-Gracia, "Occupational exposure to hepatitis E virus (HEV) in swine workers," The American Journal of Tropical Medicine and Hygiene, vol. 78, no. 6, pp. 1012-1015, 2008.

[238] M. T. Pérez-Gracia, M. L. Mateos, C. Galiana et al., "Autochthonous hepatitis E infection in a slaughterhouse worker," The American Journal of Tropical Medicine and Hygiene, vol. 77, no. 5, pp. 893-896, 2007.

[239] E. Meader, D. Thomas, R. Salmon, and M. Sillis, "Seroprevalence of hepatitis E virus in the UK farming population," Zoonoses and Public Health, vol. 57, no. 7-8, pp. 504-509, 2010.

[240] A. Schielke, V. Ibrahim, I. Czogiel et al., "Hepatitis E virus antibody prevalence in hunters from a district in Central Germany, 2013: a cross-sectional study providing evidence for the benefit of protective gloves during disembowelling of wild boars," BMC Infectious Diseases, vol. 15, no. article 440, 2015.

[241] A. Tschopp, H. Joller, S. Jeggli et al., "Hepatitis E, Helicobacter pylori and peptic ulcers in workers exposed to sewage: A Prospective Cohort Study," Occupational and Environmental Medicine, vol. 66, no. 1, pp. 45-50, 2009.

[242] S. Jeggli, D. Steiner, H. Joller, A. Tschopp, R. Steffen, and P. Hotz, "Hepatitis E, Helicobacter pylori, and gastrointestinal symptoms in workers exposed to waste water," Occupational and Environmental Medicine, vol. 61, no. 7, pp. 622-627, 2004.

[243] N. Cook and W. H. M. van der Poel, "Survival and elimination of hepatitis E virus: a review," Food and Environmental Virology, vol. 7, no. 3, pp. 189-194, 2015.

[244] S. U. Emerson, V. A. Arankalle, and R. H. Purcell, “Thermal stability of hepatitis E virus," Journal of Infectious Diseases, vol. 192, no. 5, pp. 930-933, 2005.

[245] T. Tanaka, M. Takahashi, E. Kusano, and H. Okamoto, "Development and evaluation of an efficient cell-culture system for Hepatitis E virus," Journal of General Virology, vol. 88, no. 3, pp. 903-911, 2007.

[246] P. Saint-Jacques, H. Tissot-Dupont, and P. Colson, "Autochthonous infection with hepatitis E virus related to subtype 3a, France: a case report," Annals of Hepatology, vol. 15, no. 3, pp. 438-441, 2016.

[247] H. Okamoto, M. Takahashi, T. Nishizawa, K. Fukai, U. Muramatsu, and A. Yoshikawa, "Analysis of the complete genome of indigenous swine hepatitis E virus isolated in Japan," Biochemical and Biophysical Research Communications, vol. 289, no. 5, pp. 929-936, 2001.

[248] T.-C. Li, K. Chijiwa, N. Sera et al., "Hepatitis E virus transmission from wild boar meat," Emerging Infectious Diseases, vol. 11, no. 12, pp. 1958-1960, 2005.

[249] S. Tei, N. Kitajima, K. Takahashi, and S. Mishiro, "Zoonotic transmission of hepatitis E virus from deer to human beings," The Lancet, vol. 362, no. 9381, pp. 371-373, 2003.

[250] E. P. Gibbs, "The public health risks associated with wild and feral swine," Revue scientifique et technique (International Office of Epizootics), vol. 16, no. 2, pp. 594-598, 1997.

[251] H. Sonoda, M. Abe, T. Sugimoto et al., "Prevalence of hepatitis $\mathrm{E}$ virus (HEV) infection in wild boars and deer and genetic identification of a genotype $3 \mathrm{HEV}$ from a boar in Japan," Journal of Clinical Microbiology, vol. 42, no. 11, pp. 5371-5374, 2004.

[252] A. Suárez González, G. Solís Sánchez, L. Guerra, G. V. de la Guerra, C. Á. Navascués, and R. García López, "Prevalence of immunity to hepatitis viruses in pregnant women from the health area of Gijon (Spain)," Gastroenterology \& Hepatology, vol. 27, no. 6, pp. 347-352, 2004.

[253] M. Buti, A. Dominguez, P. Plans et al., "Infrequent detection of hepatitis E virus RNA in pregnant women with hepatitis E virus antibodies in Spain," Liver International, vol. 30, no. 10, pp. 1549-1551, 2010.

[254] M. L. M. Lindemann, G. Gabilondo, B. Romero, O. M. S. De La Maza, and M. T. Pérez-Gracia, "Low prevalence of hepatitis E infection among pregnant women in Madrid, Spain," Journal of Medical Virology, vol. 82, no. 10, pp. 1666-1668, 2010.

[255] C. Renou, V. Gobert, C. Locher et al., "Prospective study of Hepatitis e Virus infection among pregnant women in France," Virology Journal, vol. 11, no. 1, article 68, 2014.

[256] J. Tabatabai, J. J. Wenzel, M. Soboletzki, C. Flux, M. H. Navid, and P. Schnitzler, "First case report of an acute hepatitis 
E subgenotype 3c infection during pregnancy in Germany," Journal of Clinical Virology, vol. 61, no. 1, pp. 170-172, 2014.

[257] R. Anty, L. Ollier, J. M. Péron et al., "First case report of an acute genotype 3 hepatitis E infected pregnant woman living in SouthEastern France," Journal of Clinical Virology, vol. 54, no. 1, pp. 76-78, 2012.

[258] M. Kaba, H. Richet, I. Ravaux et al., "Hepatitis E virus infection in patients infected with the human immunodeficiency virus," Journal of Medical Virology, vol. 83, no. 10, pp. 1704-1716, 2011.

[259] R. Jardi, M. Crespo, M. Homs et al., "HIV, HEV and cirrhosis: evidence of a possible link from eastern Spain," HIV Medicine, vol. 13, no. 6, pp. 379-383, 2012.

[260] J. A. Pineda, C. Cifuentes, M. Parr et al., "Incidence and natural history of hepatitis e virus coinfection among HIV-infected patients," AIDS, vol. 28, no. 13, pp. 1931-1937, 2014.

[261] M. Rapicetta, R. Monarca, L. A. Kondili et al., "Hepatitis e virus and hepatitis a virus exposures in an apparently healthy highrisk population in Italy," Infection, vol. 41, no. 1, pp. 69-76, 2013.

[262] G. Scotto, D. Martinelli, M. Centra et al., "Epidemiological and clinical features of HEV infection: a survey in the district of Foggia (Apulia, Southern Italy)," Epidemiology and Infection, vol. 142, no. 2, pp. 287-294, 2014.

[263] C. Renou, A. Lafeuillade, J.-F. Cadranel et al., "Hepatitis E virus in HIV-infected patients," AIDS, vol. 24, no. 10, pp. 1493-1499, 2010.

[264] A. J. Bradley-Stewart, N. Jesudason, K. Michie, A. J. Winter, and R. N. Gunson, "Hepatitis E in Scotland: assessment of HEV infection in two high-risk patient groups with elevated liver enzymes," Journal of Clinical Virology, vol. 63, pp. 36-37, 2015.

[265] A. Kenfak-Foguena, F. Schöni-Affolter, P. Bürgisser et al., "Hepatitis $\mathrm{E}$ virus seroprevalence and chronic infections in patients with HIV, Switzerland," Emerging Infectious Diseases, vol. 17, no. 6, pp. 1074-1078, 2011.

[266] M. L. Mateos-Lindemann, M. Diez-Aguilar, A. L. G. Galdamez, J. C. Galán, A. Moreno, and M. T. Pérez-Gracia, "Patients infected with HIV are at high-risk for hepatitis E virus infection in Spain," Journal of Medical Virology, vol. 86, no. 1, pp. 71-74, 2014.

[267] A. Rivero-Juarez, L. Martinez-Dueñas, A. Martinez-Peinado et al., "Absence of occult Hepatitis E virus infection among HIV immunosuppressed patients," Journal of Infection, vol. 70, no. 6, pp. 680-683, 2015.

[268] A. Rivero-Juarez, L. Martinez-Dueñas, A. Martinez-Peinado et al., "High hepatitis E virus seroprevalence with absence of chronic infection in HIV-infected patients," Journal of Infection, vol. 70, no. 6, pp. 624-630, 2015.

[269] S. Pischke, C. Schwarze-Zander, B. Bremer et al., "Hepatitis E virus seroprevalence rate in HIV-infected patients in Germany: a comparison of two commercial assays," Intervirology, vol. 58, no. 5, pp. 283-287, 2015.

[270] F. E. Keane, M. Gompels, R. P. Bendall et al., "Hepatitis E virus coinfection in patients with HIV infection," HIV Medicine, vol. 13, no. 1, pp. 83-88, 2012.

[271] A. Madejón, E. Vispo, M. Bottecchia, M. Sánchez-Carrillo, J. García-Samaniego, and V. Soriano, "Lack of hepatitis E virus infection in HIV patients with advanced immunodeficiency or idiopathic liver enzyme elevations," Journal of Viral Hepatitis, vol. 16, no. 12, pp. 895-896, 2009.

[272] O. Marion, F. Abravanel, S. Lhomme, J. Izopet, and N. Kamar, "Hepatitis E in transplantation," Current Infectious Disease Reports, vol. 18, article 8, 2016.
[273] E. B. Haagsma, H. G. M. Niesters, A. P. Van Den Berg et al., "Prevalence of hepatitis E virus infection in liver transplant recipients," Liver Transplantation, vol. 15, no. 10, pp. 1225-1228, 2009.

[274] E. B. Haagsma, A. P. van den Berg, R. J. Porte et al., "Chronic hepatitis E virus infection in liver transplant recipients," Liver Transplantation, vol. 14, no. 4, pp. 547-553, 2008.

[275] C. Buffaz, C. Scholtes, A. Dron et al., "Hepatitis E in liver transplant recipients in the Rhône-Alpes region in France," European Journal of Clinical Microbiology \& Infectious Diseases, vol. 33, no. 6, pp. 1037-1043, 2014.

[276] H. Blasco-Perrin, R. G. Madden, A. Stanley et al., "Hepatitis e virus in patients with decompensated chronic liver disease: A Prospective UK/French Study," Alimentary Pharmacology and Therapeutics, vol. 42, no. 5, pp. 574-581, 2015.

[277] K. Kikuchi, T. Yoshida, N. Kimata, C. Sato, and T. Akiba, "Prevalence of hepatitis $\mathrm{E}$ virus infection in regular hemodialysis patients," Therapeutic Apheresis and Dialysis, vol. 10, no. 2, pp. 193-197, 2006.

[278] M. L. Mateos, C. Camarero, E. Lasa, J. L. Teruel, N. Mir, and F. Baquero, "Hepatitis E virus: relevance in blood donors and other risk groups," Vox Sanguinis, vol. 75, no. 4, pp. 267-269, 1998.

[279] S. P. E. Sylvan, S. H. Jacobson, and B. Christenson, "Prevalence of antibodies to hepatitis E virus among hemodialysis patients in Sweden," Journal of Medical Virology, vol. 54, no. 1, pp. 38-43, 1998.

[280] M. Buti, R. Jardí, M. Cotrina et al., "Hepatitis E virus infection in acute hepatitis in Spain," Journal of Virological Methods, vol. 55, no. 1, pp. 49-54, 1995.

[281] C. Senosiain, A. A. González-Tallón, A. López-Sanromán et al., "Hepatitis E seroprevalence in inflammatory bowel disease," Gastroenterology \& Hepatology, vol. 39, no. 3, pp. 185-190, 2016.

[282] H. Bauer, C. Luxembourger, J.-E. Gottenberg et al., "Outcome of hepatitis $\mathrm{E}$ virus infection in patients with inflammatory arthritides treated with immunosuppressants: a French retrospective multicenter study," Medicine, vol. 94, no. 14, article e675, 2015.

[283] E. Boxall, A. Herborn, G. Kochethu et al., "Transfusion-transmitted hepatitis E in a 'nonhyperendemic' country," Transfusion Medicine, vol. 16, no. 2, pp. 79-83, 2006.

[284] P. Colson, C. Coze, P. Gallian, M. Henry, P. De Micco, and C. Tamalet, "Transfusion-associated hepatitis E, France," Emerging Infectious Diseases, vol. 13, no. 4, pp. 648-649, 2007.

[285] L. Hauser, A.-M. Roque-Afonso, A. Beylouné et al., "Hepatitis E transmission by transfusion of Intercept blood system-treated plasma," Blood, vol. 123, no. 5, pp. 796-797, 2014.

[286] P. Gallian, S. Lhomme, Y. Piquet et al., "Hepatitis e virus infections in blood donors, France," Emerging Infectious Diseases, vol. 20, no. 11, pp. 1914-1917, 2014.

[287] C. Fischer, M. Hofmann, M. Danzer, K. Hofer, J. Kaar, and C. Gabriel, "Seroprevalence and incidence of hepatitis E in blood donors in Upper Austria," PLoS ONE, vol. 10, no. 3, Article ID e0119576, 2015.

[288] P. E. Hewitt, S. Ijaz, S. R. Brailsford et al., "Hepatitis E virus in blood components: a prevalence and transmission study in southeast England," The Lancet, vol. 384, no. 9956, pp. 17661773, 2014.

[289] B. M. Hogema, M. Molier, M. Sjerps et al., "Incidence and duration of hepatitis E virus infection in Dutch blood donors," Transfusion, vol. 56, no. 3, pp. 722-728, 2016. 
[290] T. Vollmer, J. Diekmann, R. Johne, M. Eberhardt, C. Knabbe, and J. Dreier, "Novel approach for detection of hepatitis E virus infection in German blood donors," Journal of Clinical Microbiology, vol. 50, no. 8, pp. 2708-2713, 2012.

[291] J.-M. Pawlotsky, "Hepatitis E screening for blood donations: an urgent need?" The Lancet, vol. 384, no. 9956, pp. 1729-1730, 2014. 

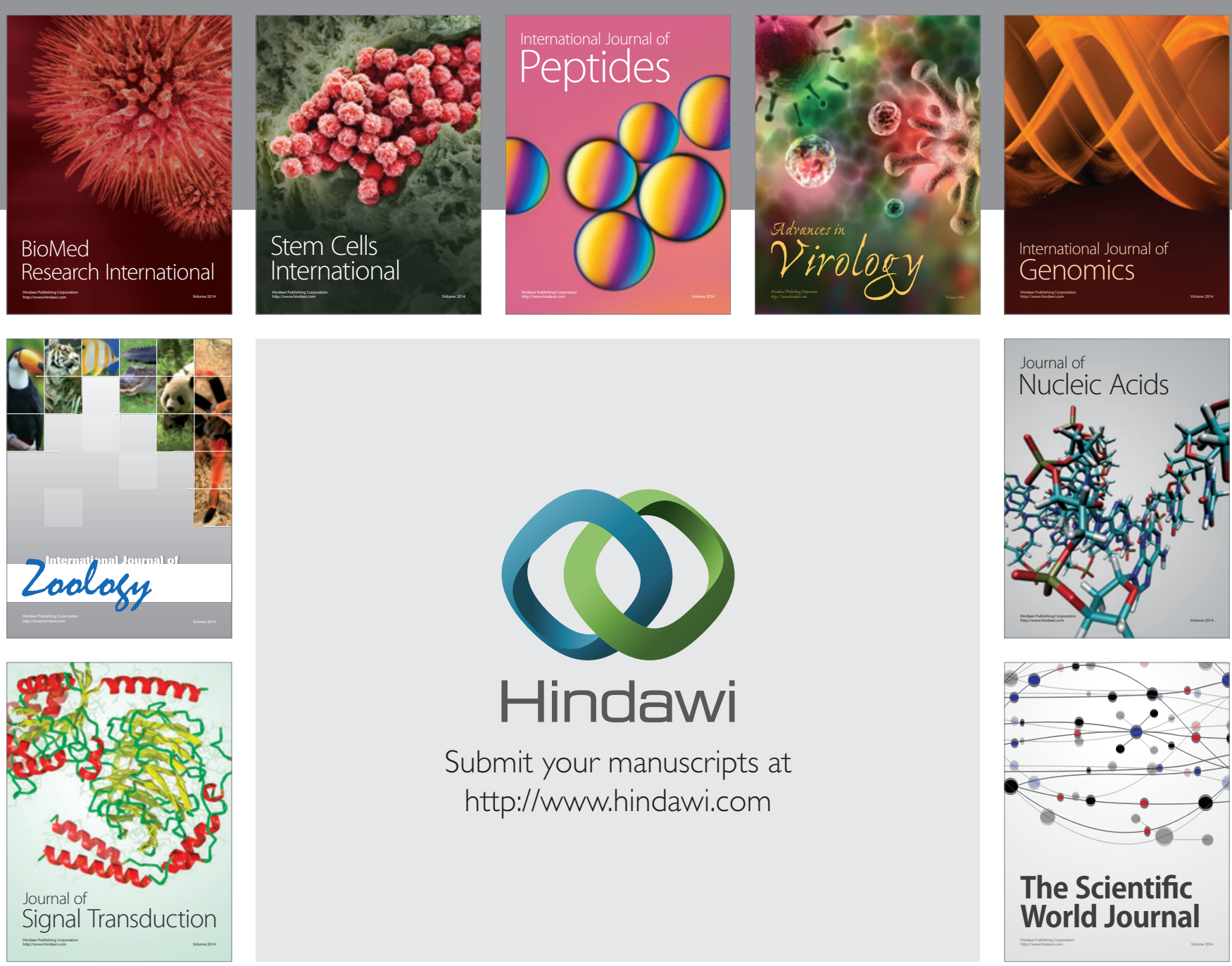

Submit your manuscripts at

http://www.hindawi.com
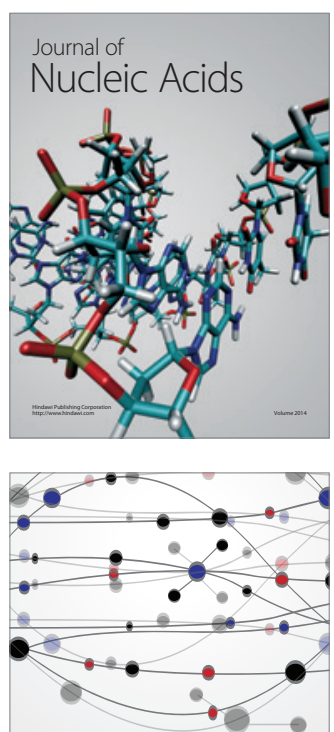

The Scientific World Journal
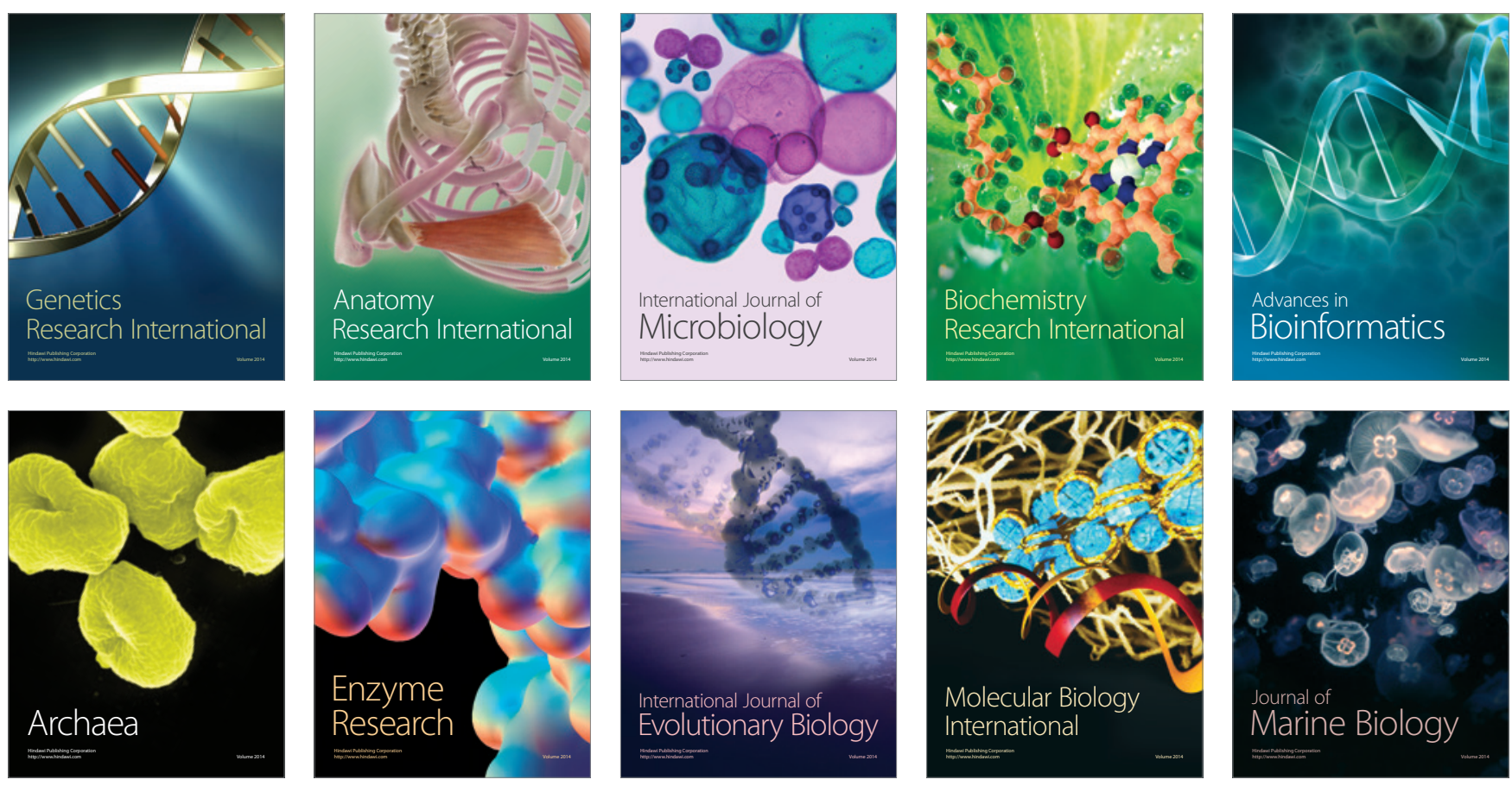